\title{
Earliest record of rhinocerotoids (Mammalia: Perissodactyla) from Switzerland: systematics and biostratigraphy
}

\author{
DAMIEN BECKER ${ }^{1}$
}

Key words: Rhinocerotidae, Amynodontidae, Hyracodontidae, Early Oligocene, north-central Jura Molasse, Switzerland

\begin{abstract}
Earliest rhinocerotoids from Switzerland are reviewed on the basis of dental remains from the earliest Oligocene north-central Jura Molasse localities of Bressaucourt (MP21/22) and Kleinblauen (top MP22). The record in Bressaucourt is restricted to Ronzotherium and Cadurcotherium, representing Switzerland's oldest, well-dated post-"Grande Coupure" large mammal association, the only occurrence of Cadurcotherium, and the earliest occurrence of rhinocerotoids in Switzerland. The correlation with high-resolution stratigraphy of this locality permitted a dating of the fauna to ca. $32.6 \mathrm{Ma}$, less than a million years after the "Grande Coupure" event. The rhinocerotoids of Kleinblauen are represented by Epiaceratherium, Ronzotherium and Eggysodon. With the presence of Plagiolophus ministri, they are the only well-dated Swiss post-"Grande Coupure" large mammal assemblage with the persistence of an endemic pre-"Grande Coupure" taxon. Moreover, the coexistence of
\end{abstract}

Epiaceratherium magnum and E. aff. magnum could indicate a new speciation within the Epiaceratherium lineage around the top of MP22. The rhinocerotoid associations of Bressaucourt with Ronzotherium - Cadurcotherium on the western side of the southernmost Rhine Graben area, and Kleinblauen with Epiaceratherium - Ronzotherium - Eggysodon on the eastern side, respectively, reveal a possible environmental barrier constituted by the Early Oligocene Rhenish sea and its eventual connection with the Perialpine sea. This one could have separated an arid area in central-eastern France from a humid area in Switzerland and Germany. These results, combined with the repartition of similar rhinocerotoid associations in Western Europe, also give new insights into an alternative earliest Oligocene dispersal route of rhinocerotoids from Asia towards Western Europe via North Italy.

\section{Introduction}

Rhinocerotoids were the most flourishing perissodactyl mammals during Tertiary times, especially in the late Middle and Late Eocene of North America and Asia (e.g., Prothero \& Schoch 1989; Prothero 1993). The primitive sister taxon of the three rhinocerotoid families (Amynodontidae, Hyracodontidae, Rhinocerotidae) was Hyrachyus (Prothero et al. 1986). This cosmopolitan tropical forest-dwelling running form occurred in Holarctic Early to Middle Eocene, when Eurasia formed one great landmass and North America was still connected to Europe across Greenland and to Asia via the Bering Strait. By the Late Eocene, however, the main intercontinental connections were disconnected, and each continent developed its own endemic faunas (e.g., Prothero et al. 1986; Prothero 1993). In Western Europe, apart from the occurrence of Hyrachyus (e.g., Grauves, France; Geiseltal, Germany; see Aguilar et al. 1997), early rhinocerotoids occurred only in the earliest Oligocene and are still poorly documented through- out this time interval. The record is so far restricted to two "true" rhinocerotid genera with Epiaceratherium and Ronzotherium, and two rhinocerotoid genera with Eggysodon and Cadurcotherium (Prothero 1993; Antoine et al. 2003). The appearance of these rhinocerotoids together with other new mammal families (e.g., Entelodontidae, Anthracotheriidae, Gelocidae, Cricetidae) coincides with the extinction/origination event named "Grande Coupure" (e.g., Stehlin 1910; Heissig 1987; Hooker 1987, 1992; Hartenberger 1998). The calibration of calcareous nannoplankton and dinocyst zones with sequence stratigraphy in Italy, and an improved correlation between the Hampshire, Paris, and Belgian basins suggest that this European faunal turnover corresponds to the time interval of ca. 33.6-33.2 Ma (ca. 33.6-33.4 Ma in the Belgian Basin after Hooker et al. 2004, 2009; i.e., ca. MP20/21 boundary of the European Mammal reference levels). After Hooker et al. (2004), it reflects a combined influence of both a global climatic change (the Oi-1 cooling event of Zachos et al. 2001) and a major invasion of mammals from Asia, while the Euro-

${ }^{1}$ Section d'archéologie et paléontologie, Office de la culture, République et Canton du Jura, Hôtel des Halles, CH-2900 Porrentruy 2, Switzerland.

E-mail:damien.becker@palaeojura.ch 


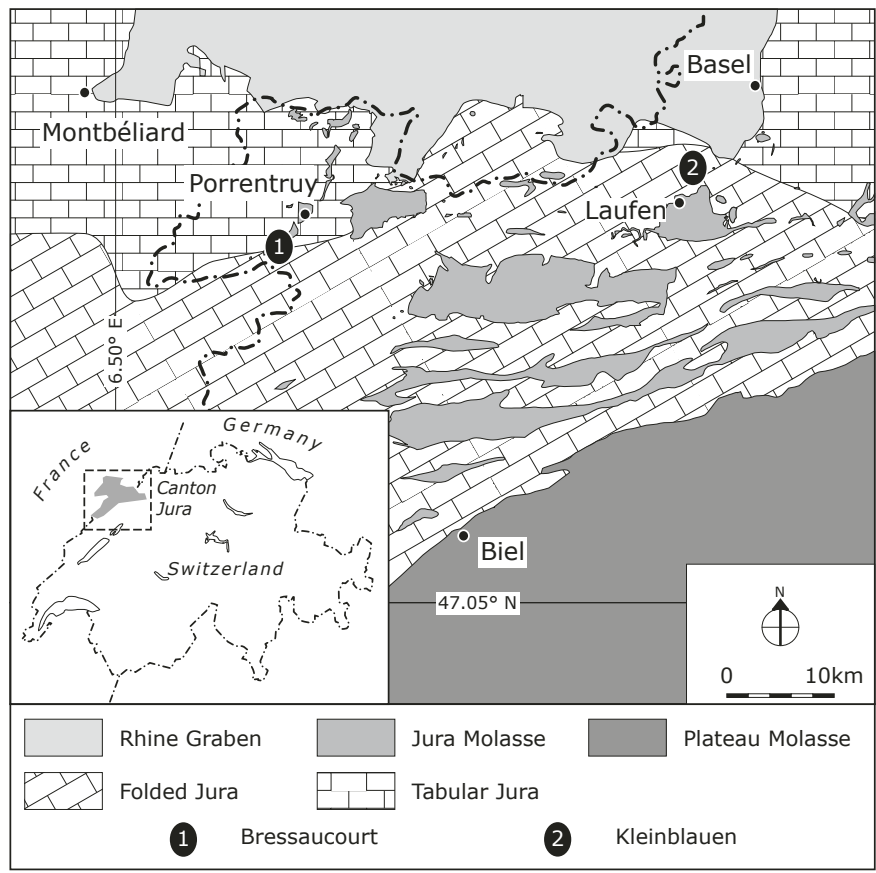

Fig. 1. Geographical and geological setting of the Early Oligocene mammal localities Bressaucourt and Kleinblauen in the north-central Jura Molasse, northwestern Switzerland.

pean and Asian continents fused again after the closure of the Turgai Strait.

In the Molasse Basin, there is no high-resolution stratigraphic record across the "Grande Coupure". The pre- and post-"Grande Coupure" faunas are reconstructed from isolated short sections or fissure-fills. In Switzerland, the only pre"Grande Coupure" faunas are the famous fissure-fills from Egerkingen (MP14; Brunet et al. 1987) and Mormont (MP1619; Hooker \& Weidmann 2000), whereas the earliest well-dated post-"Grande Coupure" ones are dated to MP22 and limited to small mammal assemblages (e.g., Balm; Engesser \& Mödden 1997). Even though earliest Oligocene rhinocerotoid remains from Switzerland are known for a long time (Stehlin 1914; Heissig 1969; Uhlig 1999; Becker 2003) from the north-central Jura Molasse localities Bressaucourt (Canton Jura, northwestern Switzerland) and Kleinblauen (Canton Basel-Landschaft, northwestern Switzerland), they are still poorly dated and the material is only partially reviewed (Fig.1). The focus of the present work is the first complete description of the specimens from Bressaucourt (Ronzotherium filholi, Cadurcotherium minus) and Kleinblauen (R. filholi, Epiaceratherium magnum, E. aff. magum, Eggysodon osborni). New stratigraphical data from the north-central Jura Molasse (Picot et al. 2005, 2008) imply that these are the earliest occurrences of rhinocerotoids and post-"Grande Coupure" large mammals from Switzerland, and for this reason their palaeobiogeographical and palaeoenvironmental implications can be discussed from a new point of view.

\section{Geological setting and taphonomy}

In the north-central Jura Molasse, earliest Oligocene deposits are controlled by transgression-regression cycles of the Rhenish sea. They belong to the Conglomérats de Porrentruy, Meeressand and Septarienton stratigraphical groups (Berger et al. 2005a, b; Picot et al. 2008). Whereas three transgression-regression cycles are known within the Rhine Graben during the Oligocene, only the first two are recorded in the Porrentruy region (Ajoie district), and only the second one in the Laufen basin (Fig. 2). Biostratigraphical data based on calcareous nannoplankton zones, dinoflagellate cyst zonation and mammal reference levels allowed the dating of these marine incursions (Picot et al. 2008). After Storni (2002) and Picot et al. (2008), the first recorded transgression corresponds to the biozone top NP21-base NP22 (ca. MP21) in the Mulhouse area and the Ajoie basin. According to the dinocyst zonation of Simaeys et al. (2005), the second one, the global Rupelian transgression,
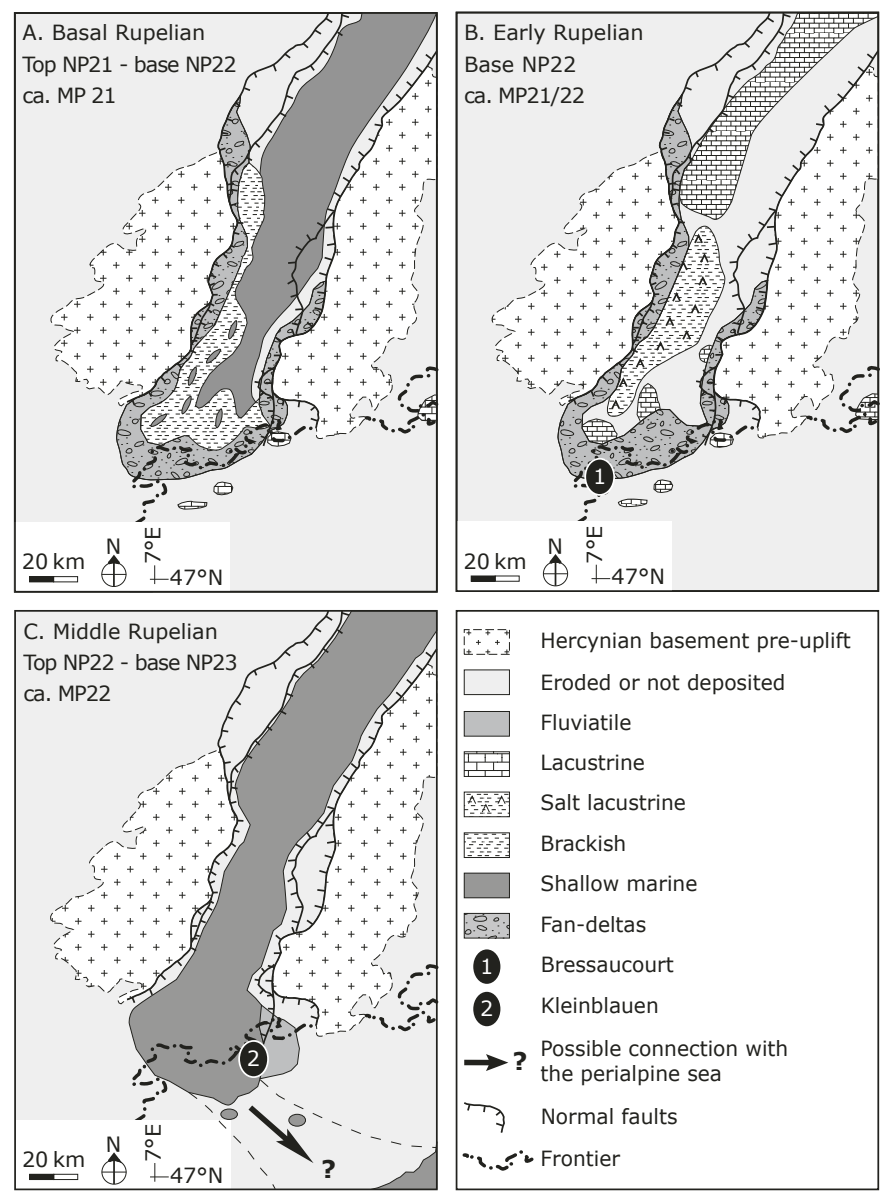

Fig. 2. Palaeogeographical maps of the southern Rhine Graben and the north-central Jura Molasse during the Early Oligocene (Fig. 2A-C), including the two first transgression-regression cycles of the Rhenish sea (modified after Berger et al. 2005b and Picot et al. 2008). The mammal-bearing deposits of Bressaucourt were recorded during the transitional continental phase between the two marine incursions (Fig. 2B), and those of Kleinblauen during the onset of the regression of the second incursion (Fig. 2C). 
simultaneously invaded the whole north-central Jura area during the NSO-2-NSO-3 (ca. top NP22-base NP23; ca. MP22). Its regression was clearly diachronous, occuring from NP23 to NP24 (ca. top MP22-MP23) in two directions, westwards and northwards.

The Bressaucourt mammal locality near Porrentruy (Canton Jura, northwestern Switzerland) was discovered by Choffat (1878), but he gave very little documentation about the outcrop. The specimens are trapped in a calcarenitic matrix-supported gravel, considered by Becker (2003) and Picot et al. (2008) as belonging to the Meeressand, according to the coordinates given by the Register of the Tertiary Mammal-bearing localities of the Naturhistorisches Museum Basel (locality CH/1085/3). However, after the indications of Choffat (1878), the locality was located north of Bressaucourt, whereas the coordinates of the Register of the Tertiary Mammal-bearing localities are south of Bresseaucourt and are in fact confused with a cerithid locality (Calcaires à Cérithes d'Ajoie Formation). The latter locality is also signaled south of Bresaucourt in the Geologischer Atlas der Schweiz (Diebold et al. 1963; Laubscher 1963). New observations of the matrix and the geological map indeed suggest that the mammal locality of Bresseaucourt corresponds to the earliest Oligocene deposits of the Conglomérats de Porrentruy, and more precisely probably to the continental interval, which is interpreted as a fluvial fan delta environment between the first and the second marine cycle (Picot et al. 2008).

The Kleinblauen locality, located north of Laufen, is slightly younger than Bressaucourt. The fossil material comes from a coarse sandstone bed (Jenny 1905; Bitterli 1945) at the top of the coastal marine deposits of the Meeressand, at the beginning of the regression of the second marine cycle (Fig. 3).

The material of both localities is mainly composed of unworn dental remains, without abrasion nor polish marks. This indicates that the bones were disarticulated (by decay or scavenging) before deposition and fossilisation and excludes a long post-mortem transport, and thus an important time averaging. However, the preservational contexts are quite different. In Bressaucourt, the material is represented by scarce isolated elements preserved in sediment gravity deposits, whereas in Kleinblauen it was found in a deltaic bone bed with sorting, transport, concentration and mixture (shark teeth are also preserved).

\section{Material and methods}

All the rhinocerotoid specimens from Bressaucourt and Kleinblauen have been reviewed to ensure their taxonomic identification. The Plagiolophus specimen (NMB-KB20) from Kleinblauen has also been reviewed to better assess the biostratigraphy of this locality.

The rhinocerotoid dental terminology follows Uhlig (1999) and Antoine (2002), and the dental measurements are taken according to Guérin (1980). For the Plagiolophus specimen, the terminology and measurements are after Remy (2004) and Franzen (2007). All dimensions are in millimetres.

\section{Abbreviations}

D, upper decideous tooth; I, upper incisive; C, upper canine; $\mathbf{P}$, upper premolar; $\mathbf{M}$, upper molar; d, lower decideous tooth; i, lower incisive; c, lower canine; p, lower premolar; m, lower molar; Mc, metacarpus; Mt, metatarsus; dext., right; sin., left; $\mathbf{L}$, length; W, width; H, crown height; TD, transversal diameter; APD, antero-posterior diameter; prox, proximal; dist, distal; dia, diaphysis. BSP, Bayerische Staatssammlung für Paläontologie und historische Geologie, Munich (Germany);IPHEP, Institut International de Paléoprimatologie, Paléontologie $\mathrm{Hu}$ maine: Évolution et Paléoenvironnements, Université de Poitiers (France); MNHN, Muséum national d'Histoire naturelle, Paris (France); NMB, Naturhistorisches Museum Basel (Switzerland); NMBE, Naturhistorisches Museum der Burgergemeinde, Bern (Switzerland); UP, Université de Provence, Centre de Sédimentologie-Paléontologie, Marseille (France).

\section{Systematic palaeontology}

Perissodactyla OwEN 1848

Rhinocerotoidea OWEN 1845

Rhinocerotidae GRAY 1821

Epiaceratherium ABEL 1910

Epiaceratherium magnum UHLIG 1999

Referred material: Kleinblauen (NMB): M1 dext. (KB84; Fig. 4c); M2 dext. (KB83; Fig. 4d); M3 dext. (KB210; Fig. 4e); p4 sin. (KB61; Fig. 4b1-b2).

Description: These cheek teeth are medium-sized and brachyodont (Tab. 1), and the three upper molars (M1-3 dext.) could belong to the same individual. There is neither enamel foldings nor cement. The enamel is thin, wrinkled at the neck, and arborescent on the top of the crowns.

The upper molars display no labial cingulum (except a weak cingulum under the parastyle), a reduced lingual cingulum under the protocone and the hypocone (even absent on M3), a weak crochet restricted to the top of the crown, a low-developed antecrochet, a weak constriction of the protocone and a metaloph groove, a rather faint bulging paracone folding flattened on the base of the crown, as well as a fine and elongated parastyle. The median valley (=medisinus) is sickle shaped, closed by a lingual cingulum, and displays a labial pit. M1-2 are four-rooted and trapezoid, with a metaloph shorter than the protoloph. The metastyle is elongated and fine. The hypocone is posterior to the metacone, the metacone folding is absent, and the posterior part of the ectoloph is concave. The parastylic groove is well-marked on M2 but less pronounced on M1, and always smooth on the base of the crown. Both the postfossette and the median valley are deep (same depth), the postfossette being limited by a continuous posterior cingulum. The anterior cingulum is waved. M3 is triangular-shaped, with a very smooth and faint ectoloph/metaloph angle, and a completely reduced metacone. The roots are not visible. The anterior and posterior cingula are rectilinear. The parastylic groove is sharp and wellmarked. 


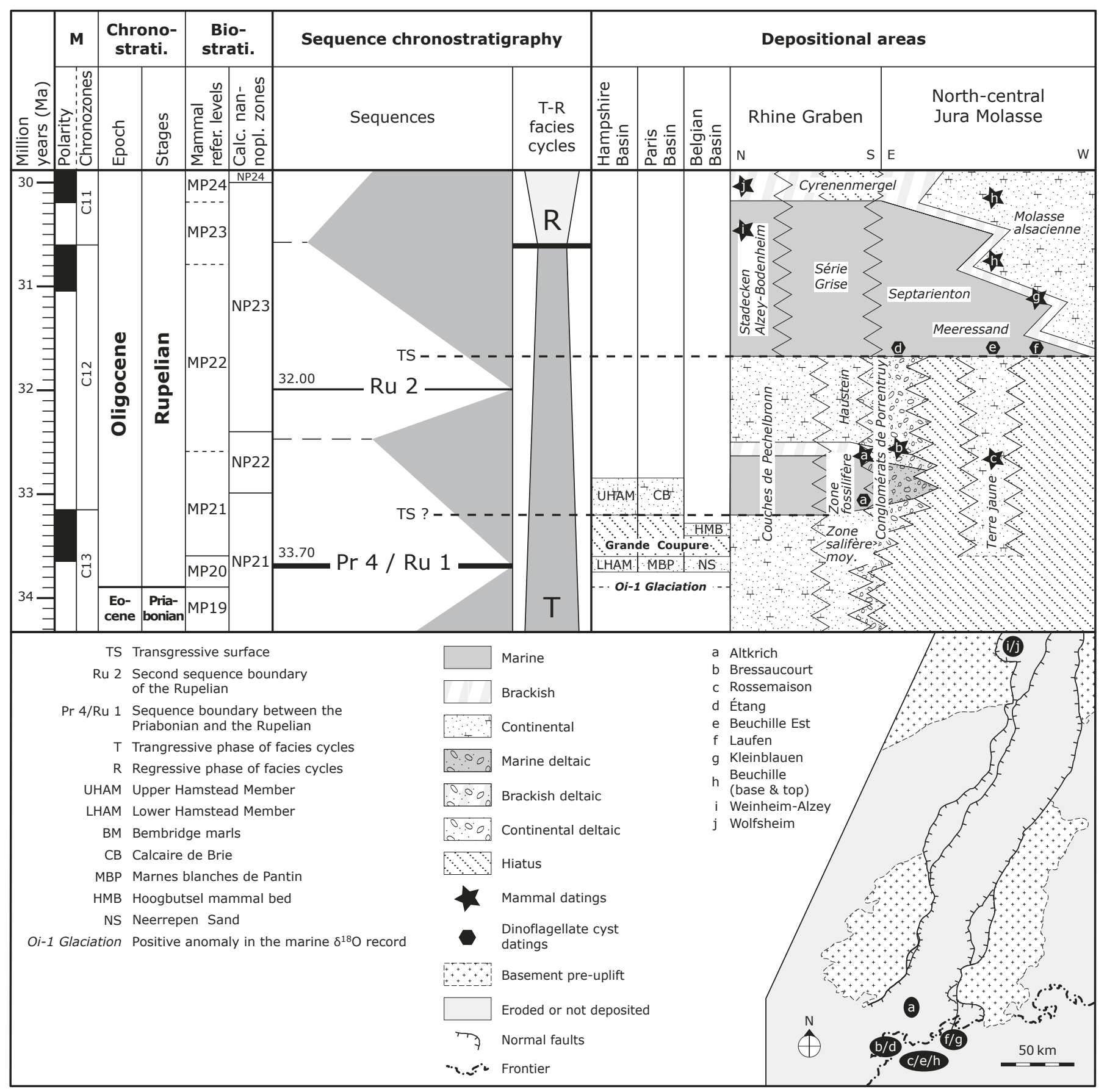

Fig. 3. Lithostratigraphical correlation chart (latest Eocene to the Early Oligocene) for the Hampshire, Paris, and Belgian basins (pro parte), and the Rhine Graben and the north-central Jura Molasse (based on Hooker et al. 2004, 2009; Picot et al. 2008). The Magnetostratigraphy (M), the Chronostratigraphy, the Mammal reference levels and the Calcareous nannoplankton zones are based on Luterbacher et al. (2004), and the sequence chronostratigraphy on Hardenbol et al. (1998). Oi-1 Glaciation: cooling event at the Eocene/Oligocene boundary based on global deep-sea oxygen and carbon isotope records (after Zachos et al. 2001). Rhine Graben and north-central Jura Molasse dating pinpoints: a, Altkrich (NP21, MP21; Storni 2002); b, Bressaucourt (MP21/22; this study); c, Rossemaison borehole (presence of Theridomys aquatilis, MP21; M. Weidmann, pers. comm., B. Engesser, identification); d, Étang (NP22-base NP23; Picot et al. 2008); e, Beuchille Est (NP22-base NP23; Picot et al. 2008); f, Laufen (NP22-base NP23; Picot 2002); g, Kleinblauen (top MP22; this study); h, Beuchille base (MP23; Becker et al. 2004) and Beuchille top (MP24; Becker et al. 2004); i,Weinheim-Alzey (MP23; Uhlig 1999); j, Wolfsheim (MP24; Mödden et al. 2000). 
Regarding p4, its shape is subrectangular with an anterior narrowing-up. It displays also an angular external groove vanishing before the neck, an angular trigonid with an acute dihedron, a metaconid and an entoconid joined to the metalophid and the hypolophid respectively, a V-shaped lingual opening of the valleys (the basic line of the posterior valley is subhorizontal and lower than that of the sloping anterior valley), a short paralophid parallel to the metalophid. The lingual cingulum is absent and the labial cingulum reduced.

Discussion: Jenny (1905), Roman (1911), and Stehlin (1914) assigned a part of the rhinocerotid remains from Kleinblauen to cf. Ronzotherium reichenaui, Eggysodon osborni and Rhinoceros (Engyodon) reichenaui (= Eggysodon reichenaui), respectively. The referred specimens bear several synapomorphies of Rhinocerotidae, such as the fusion of the ectoloph and the metaloph into an ectometaloph on M3, and the presence of antecrochet and crochet on upper molars (Prothero et al. 1989; Antoine 2002). Among the common Early Oligocene rhinocerotids, Ronzotherium differs by larger dimensions, the presence of a labial cingulum, and a continuous lingual cingulum (Heissig 1969; Brunet 1979). Protaceratherium albigense displays upper molars of smaller dimensions, a longer protoloph, no labial pit of the median valley, no crochet, more developed protocone constriction and antecrochet, and a continuous labial cingulum, only reduced under the metacone and the protocone. Its lower premolars have a labial cingulum and the lingual openings of the valleys are closed by a bolt of cingulum (Roman 1911; Hugueney \& Guérin 1981; Uhlig 1999). The dimensions (Tab. 1) and morphological features of Kleinblauen teeth are diagnostic characters of Epiaceratherium magnum (Uhlig 1999; Becker 2003): a reduction of the metacone folding, an onset of development of a crochet restricted to the top of the crown, a labial pit of the medisinus, a triangular-shaped M3, as well as an entoconid joined to the hypolophid and an anterior narrowingup of the outline in $\mathrm{p} 4$. They differ from E. bolcense by larger dimensions, a marked metacone, and the absence of a crochet on the upper molars; a trapezoid M3 and a longer paralophide on p4 (Dal Piaz 1930; Uhlig 1999). Accordingly, the referred material is assigned to E. magnum.

\section{Epiaceratherium aff. magnum UHLIG 1999}

Referred material: Kleinblauen (NMB): toothrow with P3-M1 sin. (KB7/1-7/3; Fig. 4f).

Description: The enamel of these upper cheek teeth is comparable to that of the referred specimen assigned to E. magnum. The upper premolars are broader than long, their shape is rectangular with a distal thinning down on P4 (metaloph shorter than the protoloph). The ectoloph profile is characterized by well-marked bulging paracone folding and parastyle, a sharp parastylic groove in the upper part of the crown, and faint mesostyl and metacone folding. The metastyle is not developed on P3 and slightly marked on P4. A crista, an antecrochet, and an anterior protocone groove are developed. The median valley forks labially around the crista. Both the postfossette and the median valley are deep (same depth). The metaloph is rectilinear in P3 and S-shaped in P4. P3 is submolariform to semimolariform (hypocone united to the metaloph and with a bridge to the protocone) and $\mathrm{P} 4$ is submolariform (hypocone united to the protocone and with a thin bridge to the metaloph). The lingual wall is marked by a smooth groove. The labial cingulum is absent. The anterior cingulum is rectilinear on P3 and slightly waved on P4. The posterior cingulum is continuous and lowered on the level of the posfossette. The lingual cingulum is strong and continuous, elevated under the protocone and the hypocone. M1 is closer to the referred specimen assigned to E. magnum (NMB-KB84; Fig. 4c). The main differences are a well-developed protocone constriction and a strongly marked antecrochet.

Discussion: Uhlig (1999) and Becker (2003) did not review these specimens. They display a more advanced dental wear than the specimens referred to E. magnum and belonged undeniably to a distinct individual. Their dimensions (Tab.1) and morphological features, such as the strong lingual cingulum elevated under the main cones, the visible metacone folding, and the presence of a crista on the premolars, are characteristic of the genus Epiaceratherium and closer to E. magnum. However, the well-developed protocone constriction and the strongly marked antecrochet on M1, as well as the anterior protocone groove and the lingual wall marked by a smooth groove on $\mathrm{P} 3-4$, point to derived characters similar to those described by Uhlig (1999) for the Epiaceratherium specimens from Offenheim (MP23, Germany). This author assigned this material to E. aff. magnum. The richness of Kleinblauen specimens does not allow currently to make a decision regarding a new species identification. Following the proposition of Uhlig (1999), the referred specimens are provisionally identified as E. aff. magnum.

\section{Ronzotherium AYMARD 1854 \\ Ronzotherium filholi (OSBORN 1900)}

Referred material: Kleinblauen (NMB): P3 dext. (KB1; Fig. 4h); $\mathrm{P} 3$ dext. (KB5); P4 dext. (KB2); P4 sin. (KB6); P4 sin. (KB63a; Fig. 4i); toothrow with M1-M3 sin. (KB25); toothrow with M2M3 dext. (KB27); M1 sin. (KB144a; Fig. 4j); M1 dext. (KB3; Fig. 4k); M3 sin. (KB8; Fig. 4 1); m3 sin (KB13). Bressaucourt (NMB): part of juvenile mandible (d1)-d2-d3 dext. (OB7; Fig. 4g1-g2).

Description: The referred adult cheek teeth from Kleinblauen are medium- to large-sized and brachyodont (Tab. 1), without enamel foldings nor cement. The enamel is medium-thick and wrinkled. The upper premolars P3-4 are three-rooted, widened, trapezoid-shaped (lingual wall slightly shorter than the labial wall), and premolariform to submolariform. The ectoloph profile is characterized by a flattened parastyle, a smooth paracone, and a metacone folding flattened at the base of the crown. The hypocone is united to the protocone. It is separated from the metaloph at the top of the crown, but united to it with a thin bridge at the base. The metaloph is S-shaped. The hypocone is developed distally and, mainly on $\mathrm{P} 4$, is more labial 

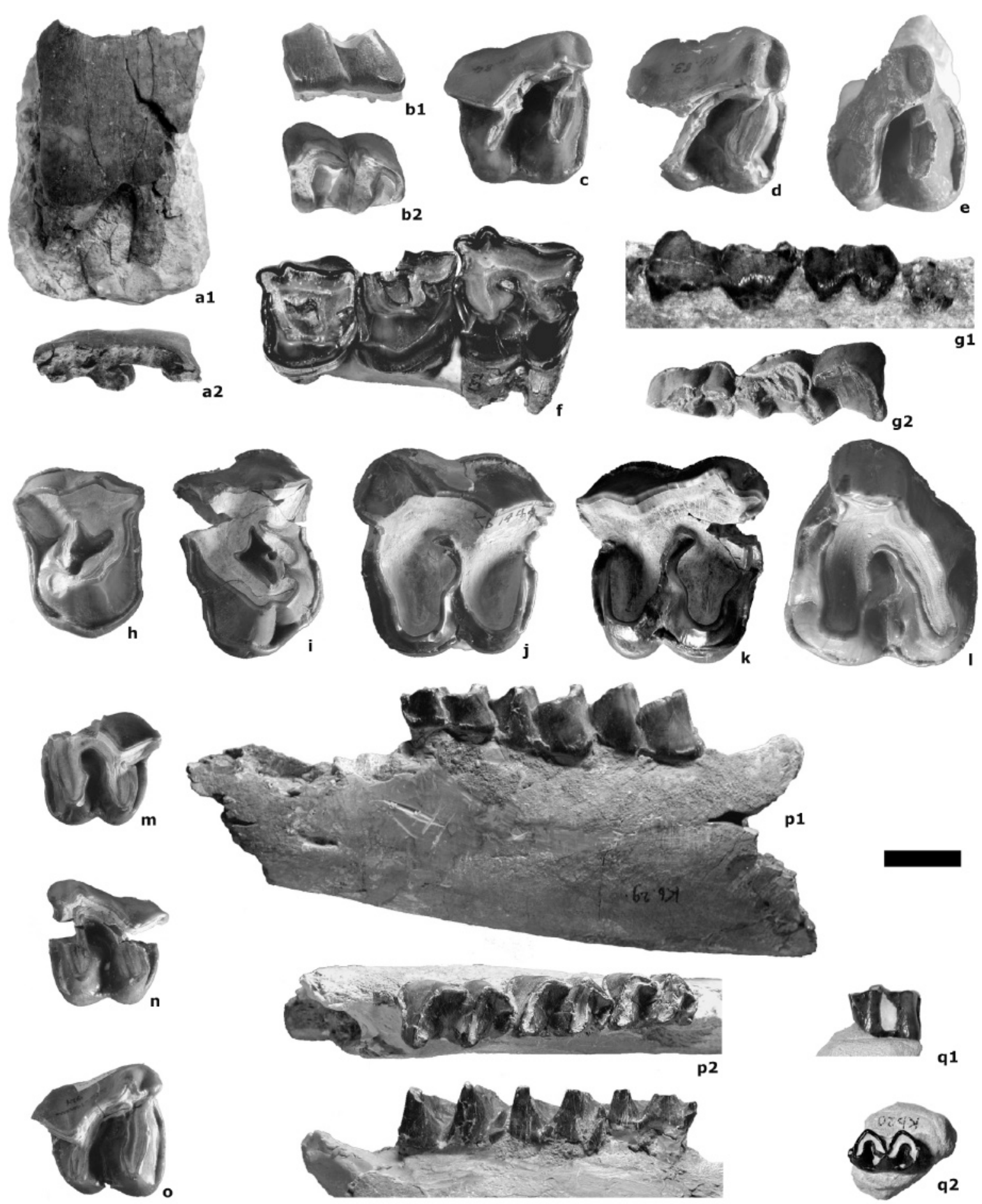

q1

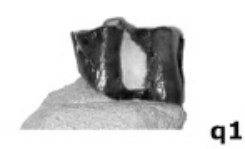

p3

Fig. 4. Rhinocerotoid dental remains from Bressaucourt and Kleinblauen localities (Early Oligocene, north-central Jura Molasse, northwestern Switzerland), Scale bar is $2 \mathrm{~cm}$. Cadurcotherium minus, Bressaucourt; $\boldsymbol{a}$, m2 dext. (NMBE-D3473), labial view (1), occlusal view (2). Epiaceratherium magnum, Kleinblauen; b, p4 sin. (NMB-KB61), labial view (1), occlusal view (2); c, M1 dext. (NMB-KB84), occlusal view; d, M2 dext. (NMB-KB83), occlusal view; e, M3 dext. (NMB-KB210), occlusal view. Epiaceratherium aff. magnum, Kleinblauen; f, P3-M1 sin. (NMB-KB7/1-7/3), occlusal view. Ronzotherium filholi, Bressaucourt; g, part of juvenile mandible with (d1)-d2-d3 dext. (NMB-OB7), labial view (1), occlusal view (2). Ronzotherium filholi, Kleinblauen; h, P3 dext. (NMB-KB1), occlusal view; i, P4 sin. (NMB-KB63a), occlusal view; j, M1 sin. (NMB-KB144a), occlusal view; k, M1 dext. (NMB-KB3), occlusal view; l, M3 sin. (NMB-KB8). Eggysodon osborni, Kleinblauen; m, M1 sin. (NMB-KB62), occlusal view; n, M2 sin. (NMB-KB64a), occlusal view; o, M2 dext. (NMB-KB144), occlusal view; p, part of juvenile mandible with d4-m2 sin. (NMB-KB29), labial view (1), occlusal view (2), lingual view (3). Plagiolophus ministri, Kleinblauen; q, m2 sin. (NMB-KB20), labial view (1), occlusal view (2). 
than the protocone. The cingulum is strong, continuous on the four sides. The labial one is less developed and the lingual one is high and elevated under the protocone and the hypocone. The postfossette is narrow and shallow. There are neither protocone constriction nor antecrochet, but a crista and a thin crochet. The latter is developed in a small fossette on $\mathrm{P} 4$ specimen NMB-KB63a (Fig. 4i). The lingual wall is curved and marked by a smooth lingual groove on P3, acute and well-developed on $\mathrm{P} 4$.

The upper molars M1-2 are four-rooted. The lingual cingulum forms a bolt closing the incised S-shaped median valley and is reduced under the hypocone. The labial cingulum is reduced under the paracone. The antecrochet is developed, but the protocone constriction is absent. The paracone folding is strong and the parastyle rather acute and lengthened forward. The mesostyle and the metacone folding are absent, the posterior part of the ectoloph is straight. The crista, the crochet and the postfossette are not observable due to the wear of the specimens. M3 is quadrangular-shaped with a posterior groove on the ectometaloph. The protoloph is transverse and unconstricted. A stout antecrochet is poorly developed. The cingulum is reduced under the paracone and labially prolongated inside the median valley in a tuber.

Tooth $\mathrm{m} 3$ displays a developed external groove vanishing before the neck. The anterior cingulum is strong, the labial one continuous and the lingual one reduced backward. The trigonid is angular, with a right dihedron. The metaconid and the entoconid are joined respectively with the metalophid and the hypolophid. The paralophid is slightly curved backward. The valley openings are close to the neck, the anterior one V-shaped and higher than the U-shaped posterior one. The basic line of the anterior valley is sloping and the posterior valley is subhorizontal.

The lower milk teeth of specimen NMB-OB7 (Fig. 4g1-g2) from Bressaucourt display a labial cingulum reduced under the marked external groove. The base of the corpus mandibulae is straight (height under $\mathrm{d} 1 / 2=55.5 ; \mathrm{d} 2 / 3=56.5$; $\mathrm{d} 3 / 4=59.0$ ). The posterior valley opening is $\mathrm{V}$-shaped, the hypolophid transverse, and the protoconid folding developed. Tooth $\mathrm{d} 1$ is tworooted. Tooth $\mathrm{d} 2$ displays an anterior groove on the ectolophid, a metaconid fused with the metalophid, and a double paralophid with short transverse and sagittal branches. The metaconid of $\mathrm{d} 3$ is mesially constricted but not isolated. The paralophid is more developed than that of $\mathrm{d} 2$, displaying longer transverse and sagittal branches.

Discussion: Numerous dental features of the referred material (presence of an antecrochet on the upper molars, M3 with the ectoloph and the metaloph fused into an ectometaloph) point to Rhinocerotidae (Prothero et al. 1989; Antoine 2002). The specimens differ from the European late Early and Late Oligocene Protaceratherium albigense mainly by their larger dimensions, a less developed molarisation of the upper premolars, and a more developed lingual cingulum on the upper molars (Uhlig 1999; Lihoreau et al. 2009). Compared to Epiaceratherium magnum, the specimens are larger, P3-4 less molarized, the postfossettes and median valleys of the upper cheek teeth less deep, the hypocone stronger on the upper premolars, and M3 quadrangular-shaped (Uhlig 1999). The labial cingulum is developed on $\mathrm{m} 3$. The latter bears a longer paralophid, a right dihedron of the trigonid, a higher lingual opening of the anterior valley, and a U-shaped posterior valley. The lower milk teeth from Bressaucourt differ also from E. magnum by having a labial cingulum and a protoconid folding, as well as an ectolophid anterior groove and a shorter paralophid sagittal branch on $\mathrm{d} 2$.

The referred cheek teeth display dimensions (Tab. 1) and morphological features typical of Ronzotherium, such as the brachyodonty, pre- to submolariform P3-4, molars with a strong antecrochet, and lower cheek teeth with a high lingual opening of the anterior valley (trigonid higher than talonid). However, the dimensions hardly allow an identification to the species level.

The poor fossil record of the Mongolian $R$. brevirostre permits nevertheless to point to morphological differences with the Kleinblauen and Bressaucourt specimens, such as a moderately long paralophid, no labial nor lingual cingula, and a short talonid on m3, and a one-rooted d1 (Heissig 1969; Brunet 1979; Dashzeveg 1991).

The specimens from Kleinblauen bear a combination of diagnostic characters of $R$. filholi, including narrow and shallow postfossettes, broad upper premolars with a S-shaped metaloph, a distally strong hypocone and a strong lingual cingulum; upper molars with a reduced lingual cingulum; lower molars with a continuous labial cingulum, a reduced lingual cingulum, and a U-shaped posterior valley (Brunet 1979). They can be distinguished from $R$. velaunum and $R$. romani by their intermediary state. $R$ velaunum is more primitive with more developed cingula, more shallow postfossettes on upper cheek teeth, and higher lingual openings of valleys on lower cheek teeth. Ronzotherium romani bears more derived features as reduced cingula, a deeper and broader postfossette, sub- to molariform P3-4, a straight metalophe on upper premolars, and a weaker external groove on lower cheek teeth (Heissig 1969; Brunet 1979; Emery 2004). The milk teeth from Kleinblauen display a short sagittal branch of the paralophid on $\mathrm{d} 2$ and a longer one on $\mathrm{d} 3$, very similar to $R$. filholi from Villebramar. On the other hand, R. velaunum from Ronzon and Lagny-Thorigny differs by its more developed paralophid on $\mathrm{d} 2-3$ and $R$. romani from Gaimersheim by a reduced $\mathrm{d} 2$ (Heissig 1969; Brunet 1979).

Therefore, based essentially on diagnostic dental morphology, the specimens from Kleinblauen and Bressaucourt can be referred to $R$. filholi with confidence. This confimrs the assignations of Brunet (1979) and Becker (2003). According to Brunet (1979) - and contrary to the evolution in separate lineages ( $R$. velaunum; $R$. filholi filholi - R. f. elongatum; $R$. f. filholi - R. f. romani) suggested by Heissig (1969) - Ronzotherium filholi seems to correspond to a transitional form between the primitive $R$. velaunum and the derived $R$. romani into an anagenetic evolution. 
Amynodontidae ScOTT \& OsBORN 1883

Amynodontinae SCOTT \& OsBORN 1883

Cadurcotherium GERVAIs 1873

Cadurcotherium minus FILHOL 1880

Referred material: Bressaucourt (NMBE): m2 dext. (D3473; Fig. 4a1-a2).

Description: The specimen is two-rooted, mesodont (Table 1; Hypsodonty Index sensu Guérin 1980: $100 \times \mathrm{H} / \mathrm{L}=110.2$ ), very narrow, and lengthened (transverse reduction). The lingual side of the tooth is still trapped in its conglomeratic matrix and therefore observable only in the upper part of the crown. The paralophid is very short, the lingual branch of the metalophid is short and oblique, and the hypolophid is poorly developed (almost sagittal) and distally tapered and elongated on the upper part of the crown. The labial side of the tooth is very slightly convex and the external groove is absent. The valleys are lingually open, the anterior one is weakly marked and the posterior one slightly more developed. No labial cingulum is present.

Discussion: The referred specimen bears the main synapomorphies of the lower molars of Amynodontinae (elongated, lost external groove, valleys open lingually). According to Roman \& Joleaud (1908), Osborn (1923), Wall (1989), Bonis (1995), and Lucas (2006), its dental morphology displays diagnostic characters of the genus Cadurcotherium (elongated and very narrow, absence of external groove, rather developed hypsodonty, short and oblique lingual branch of the metalophid). Usually, the Cadurcotherium lower cheek teeth bear also a marked W-shaped lingual cingulum (see the specimens from the old collection of the Phosphorites du Quercy: Cadurcotherium cayluxi, coll. NMB QP591; Cadurcotherium minus, in Roman \& Joleaud 1908, pl. III-2), but this character cannot be observed on the Bressaucourt specimen. They can also display a weak labial cingulum on the anterior part, particularly on $\mathrm{m} 3$. The latter character, which seems to correspond to an intrageneric variation, is not present on the Bressaucourt specimen. Based on size differences, Roman \& Joleaud (1908) separated the Cadurcotherium genus in Europe into three successive species (C. minus, C. cayluxi, C. nouleti). However, following Bonis (1995), C. nouleti is probably a synonym of $C$. cayluxi, due to insignificant variations in dimensions, and only the succession $C$. minus - C. cayluxi is probable.

The Cadurcotherium cayluxi specimens from the Phosphorites du Quercy (Roman \& Joleaud 1908, pl. II-1, 2) and Garouillas (Bonis 1995) differ essentially from the Bressaucourt specimen by larger dimensions (Tab. 1). On the other hand, the latter displays morphology and dimensions closer to Cadurcotherium minus from the Phosphorites du Quercy illustrated by Roman \& Joleaud (1908; pl. III-2). In the same way, m2 illustrated by Roman \& Joleaud (1908; pl. III-3) and identified as $C$. cayluxi is close to $\mathrm{m} 2$ from Bressaucourt, identified as C. cayluxi by Stehlin (1914). In fact, these two specimens shoud be ascribed to Cadurcotherium minus.
Hyracodontidae COPE 1879

Eggysodontinae BREUNING 1923

Eggysodon RoMAN 1910

Eggysodon osborni (SCHLOSSER 1902)

Referred material: Kleinblauen (NMB): toothrow with broken P4-M3 dext. (KB14); broken M1 sin. (KB62; Fig. 4 m); M2 sin. (KB64a; Fig. 4n); M2 dext. (KB144; Fig. 4o); mandible c dext. and $\mathrm{c}-(\mathrm{d} 1)-\mathrm{p} 2-\mathrm{m} 3 \mathrm{sin}$. (KB28); part of juvenile mandible with d4-m2 sin. (KB29; Fig. 4p1-p3); p4 dext. (KB11); p4 sin. (KB12); p4 sin. (KB29).

Description: The mandibles are spindly and small-sized (symphysis anterior margin-mandibular angle length $=337.0$; symphysis posterior margin-mandibular angle $=287.0$; diameter under $\mathrm{p} 4 / \mathrm{m} 1=24.5$; Lp2 $-\mathrm{m} 3$ toothrow length $=152.0$; Lp2-4 =66.0; Lp3-4 = 46.5; Lm = 86.0). The referred specimen (NMB-KB28) is broken in front of the canines, only the i $2 \mathrm{sin}$. socket is preserved. It displays a socket for a likely one-rooted $\mathrm{d} 1$, a broad and nearly horizontal mandibular symphysis, a straight ventral profile (height under p2/3 $=47.5 ; \mathrm{p} 3 / 4=49.5$; $\mathrm{p} 4 / \mathrm{m} 1=53.5 ; \mathrm{m} 1 / 2=55.5 ; \mathrm{m} 2 / 3=57.0$ ), a ramus inclined forward, a strong angle and a rather developed processus coronoideus. It bears three foramen mentale located under the canine, under p2 and under p3. The posterior margin of the symphysis is short (in front of $\mathrm{p} 2$ ). The fragmentary juvenile specimen (NMB-KB29; Fig. 4p1-p3) displays a straight ventral profile and a foramen mentale located under the $\mathrm{d} 2 / 3$ sockets.

The canines of the specimen NMB-KB28 are large (Tab. 1). The roots are distally strongly curved and they are double as high than the crowns. The cross section of the crowns is oval shaped, with a sharp distal edge and a smooth mesial worn edge.

The enamel of the referred teeth is thin. It is wrinkled at the neck and arborescent on the top of the crown of upper checkteeth, and just wrinkled on lower cheek teeth and canines. The cheek teeth are small-sized and the crowns low (Tab. 1; brachyodont type). The only upper premolar and M3 are represented by the specimen NMB-KB14, but the labial side of this part of the maxillar is strongly damaged. P4 displays a strong continuous lingual cingulum, mesially and distally elongated. It is submolariform with an oblique metaloph united to the hypocone by a weak bridge. M1-2 display simple structures, without crochet nor crista nor protocone constriction, but just a low and poorly developed antecrochet. The median valley is S-shaped, lingually widened, and closed by a cingulum bolt. The anterior and posterior cingula are marked and continuous, and the lingual cingulum is reduced under the main cusps. The ectoloph profile is concave backward with just a very weak metacone folding on specimen NMB-KB144 (Fig. 4o). The paracone folding is strong and smooth, but flattened on the base of the crown. The parastyle and the metastyle are elongated and acute. M3 displays a curved median valley closed by a weak lingual cingulum, reduced under the protocone and the hypocone. The anterior cingulum is present, while the posterior one is absent.

Tooth p2 displays a smooth external groove. The paralophid, the lingual branches of the metalophid and the hypolophid are

8 D. Becker 
Table 1. Dental measurements (in mm) of the teeth of Epiaceratherium magnum, Epiaceratherium aff. magnum, Ronzotherium filholi, Cadurcotherium minus, Eggysodon osborni and Plagiolophus ministri from the referred localities (Bressaucourt and Kleinblauen) and from their main localities. $\mathbf{L}$, labial length of the tooth; W, maximum width of the tooth, the absolute width on M3 (sensu Guérin 1980); ( ), estimation; [ ], range value.

\begin{tabular}{|c|c|c|c|c|c|c|c|}
\hline Taxa & Localities (housing inst.) & References & Tooth & $\mathbf{n}$ & $\mathbf{L}$ & $\mathbf{W}$ & $\mathbf{H}$ \\
\hline \multirow[t]{8}{*}{ Epiaceratherium magnum } & Kleinblauen (NMB-KB84) & Becker 2003 and this study & M1 & 1 & 36.0 & 40.0 & $(23.0)$ \\
\hline & Möhren 13 (BSP) & from illustrations of Uhlig 1999 & & 3 & $34.8[34.0-35.5]$ & $40.0[39.5-40.5]$ & $36.2[35.0-47.0]$ \\
\hline & Kleinblauen (NMB-KB83) & Becker 2003 and this study & M2 & 1 & 41.5 & 43.5 & $(27.0)$ \\
\hline & Möhren 13 (BSP) & from illustrations of Uhlig 1999 & & 3 & $39.5[38.0-41.0]$ & $43.0[42.0-45.0]$ & $37.3[37.0-37.5]$ \\
\hline & Kleinblauen (NMB-KB210) & Becker 2003 and this study & M3 & 1 & 37.0 & 43.5 & $(22.5)$ \\
\hline & Möhren 13 (BSP) & from illustrations of Uhlig 1999 & & 3 & $37.6[37.0-38.0]$ & $45.3[44.0-46.5]$ & - \\
\hline & Kleinblauen (NMB-KB61) & Becker 2003 and this study & $\mathrm{p} 4$ & 1 & 32.0 & 21.0 & $(15.0)$ \\
\hline & Möhren 13 (BSP) & from illustrations of Uhlig 1999 & & 4 & $29.5[28.5-31.0]$ & $21.75[21.0-23.5]$ & $17[16.5-18.0]$ \\
\hline \multirow[t]{5}{*}{ E. aff. magnum } & Kleinblauen (NMB-KB7/1) & this study & P3 & 1 & 26.0 & 33.5 & - \\
\hline & Offenheim (BSP) & from illustrations of Uhlig 1999 & & 1 & 28.0 & $(37.0)$ & - \\
\hline & Kleinblauen (NMB-KB7/2) & this study & $\mathrm{P} 4$ & 1 & $(27.0)$ & - & - \\
\hline & Offenheim (BSP) & from illustrations of Uhlig 1999 & & 1 & 31.0 & 41.5 & - \\
\hline & Kleinblauen (NMB-KB7/3) & this study & M1 & 1 & 34.0 & 39.0 & - \\
\hline \multirow[t]{16}{*}{ Ronzotherium filholi } & Kleinblauen (NMB-KB1,5) & Becker 2003 and this study & $\mathrm{P} 3$ & 2 & $34.25[34.0-34.5]$ & $46.75[46.0-47.5]$ & - \\
\hline & Villebramar (IPHEP, MNHN, NMB, UP) & Brunet 1979 & & 15 & $31.4[27.0-39.0]$ & $43.7[39.0-50.0]$ & - \\
\hline & Kleinblauen (NMB-KB2,6,63a) & Becker 2003 and this study & $\mathrm{P} 4$ & 3 & $37.3[34.0-40.0]$ & $53.6[52.5-54.5]$ & - \\
\hline & Villebramar (IPHEP, MNHN, NMB, UP) & Brunet 1979 & & 13 & $36.0[34.0-41.5]$ & $49.0[46.0-53.0]$ & - \\
\hline & Kleinblauen (NMB-KB3,25,144a) & Becker 2003 and this study & M1 & 3 & $46.8[41.0-50.0]$ & $53.2[51.0-54.5]$ & - \\
\hline & Villebramar (IPHEP, NMB, UP) & Brunet 1979 & & 9 & $45.4[41-50.0]$ & $51.3[47.0-57.0]$ & - \\
\hline & Kleinblauen (NMB-KB25,27) & Becker 2003 and this study & M2 & 2 & $54.5[53.0-56.0]$ & $62.25[58.5-66.0]$ & - \\
\hline & Villebramar (IPHEP, NMB, UP) & Brunet 1979 & & 8 & $51.9[47.0-59.0]$ & $58.6[53.0-65.0]$ & - \\
\hline & Kleinblauen (NMB-KB8,25,27) & Becker 2003 and this study & M3 & 3 & $47.5[46.0-50.5]$ & $61.7[59.5-64.0]$ & - \\
\hline & Villebramar (IPHEP, UP) & Brunet 1979 & & 10 & $45.3[42.0-49.0]$ & $57.8[53.0-64.0]$ & - \\
\hline & Kleinblauen (NMB-KB13) & Becker 2003 and this study & $\mathrm{m} 3$ & 1 & 52.0 & 31.5 & - \\
\hline & Villebramar (IPHEP, MNHN, NMB, UP) & Brunet 1979 & & 15 & $47.6[41.0-50.0]$ & $31.3[28.0-34.0]$ & - \\
\hline & Bressaucourt (NMB-OB7) & Becker 2003 and this study & $\mathrm{d} 2$ & 1 & 25.0 & 12.0 & - \\
\hline & Villebramar (IPHEP) & Brunet 1979 & & 3 & $28.7[28.0-30.0]$ & $11.5[11.0-12.0]$ & - \\
\hline & Bressaucourt (NMB-OB7) & Becker 2003 and this study & $\mathrm{d} 3$ & 1 & 39.5 & 17.0 & - \\
\hline & Villebramar (IPHEP) & Brunet 1979 & & 5 & $40.8[38.0-43.0]$ & $18.8[17.0-21.0]$ & - \\
\hline \multirow[t]{2}{*}{ Cadurcotherium minus } & Bressaucourt (NMBE-D3473) & this study & $\mathrm{m} 2$ & 1 & 44.0 & 14.0 & 48.5 \\
\hline & Phosphorites du Quercy (NMB) & this study & & 2 & $40.75[40.5-41.0]$ & 15.5 & 42.0 \\
\hline \multirow[t]{30}{*}{ Eggysodon osborni } & Kleinblauen (NMB-KB62) & Becker 2003 and this study & M1 & 1 & - & 29.5 & - \\
\hline & Möhren 13 (BSP) & from illustrations of Uhlig 1999 & & 4 & $29.5[28.5-30.5]$ & $31.25[31.0-32.0]$ & $(20)$ \\
\hline & Kleinblauen (NMB-KB64a,144) & Becker 2003 and this study & M2 & 2 & $33.5[33.0-34.0]$ & $33.75[33.0-34.5]$ & - \\
\hline & Möhren 13 (BSP) & from illustrations of Uhlig 1999 & & 1 & 32.5 & 34.0 & (24) \\
\hline & Kleinblauen (NMB-KB28) & Becker 2003 and this study & $\mathrm{c}$ & 2 & $19.0[19.0-19.0]$ & $13.5[13.0-13.5]$ & $27.5[26.0-29.0]$ \\
\hline & Möhren 13 (BSP) & Uhlig 1999 & & 6 & $16.25[13.5-20.0]$ & $10.5[9.0-11.0]$ & $20.5[18.0-24.0]$ \\
\hline & Lagny-Torigny (MNHN) & Uhlig 1999 & & 1 & 14.0 & 11.0 & 23.0 \\
\hline & Kleinblauen (NMB-KB28) & Becker 2003 and this study & $\mathrm{p} 2$ & 1 & 18.0 & 13.0 & - \\
\hline & Möhren 13 (BSP) & from illustrations of Uhlig 1999 & & 2 & $19.0[17.0-21.0]$ & $11.5[11.0-12.0]$ & $(12.0)$ \\
\hline & Lagny-Torigny (MNHN) & from photograph of Bonis \& Brunet 2005 & & 1 & 19.0 & 11.5 & $(13.5)$ \\
\hline & Kleinblauen (NMB-KB28) & Becker 2003 and this study & p3 & 1 & 22.5 & 16.5 & - \\
\hline & Möhren 13 (BSP) & from illustrations of Uhlig 1999 & & 3 & $21.2[18.5-25.5]$ & $14.3[13.5-15.0]$ & $12.75[10.5-15.0]$ \\
\hline & Lagny-Torigny (MNHN) & from photograph of Bonis \& Brunet 2005 & & 1 & 22.0 & 15.0 & 14.0 \\
\hline & Kleinblauen (NMB-KB11,12,28,29) & Becker 2003 and this study & $\mathrm{p} 4$ & 4 & $24.75[23.0-25.5]$ & $17.1[15.5-18.5]$ & 20.5 \\
\hline & Möhren 13 (BSP) & from illustrations of Uhlig 1999 & & 3 & $22.8[21.0-25.0]$ & $15.7[15.0-16.0]$ & $10.8[10.0-12.0]$ \\
\hline & Lagny-Torigny (MNHN) & from photograph of Bonis \& Brunet 2005 & & 1 & 24.0 & 15.5 & 12.0 \\
\hline & Kleinblauen (NMB-KB28,29) & Becker 2003 and this study & $\mathrm{m} 1$ & 2 & $25.5[23.0-28.0]$ & 17.5 & - \\
\hline & Möhren 13 (BSP) & from illustrations of Uhlig 1999 & & 2 & 26.5 & $18.25[18.0-18.5]$ & 10.0 \\
\hline & Villebramar (IPHEP) & Brunet 1979 & & 1 & 30.0 & 19.0 & - \\
\hline & Lagny-Torigny (MNHN) & from photograph of Bonis \& Brunet 2005 & & 1 & 25.0 & 17.0 & (7) \\
\hline & Kleinblauen (NMB-KB28,29) & Becker 2003 and this study & $\mathrm{m} 2$ & 2 & $30.5[30.0-31.0]$ & $19.25[18.5-20.0]$ & - \\
\hline & Möhren 13 (BSP) & from illustrations of Uhlig 1999 & & 3 & $27.8[27.0-29.5]$ & $18.8[18.0-19.5]$ & $10.25[10.0-10.5]$ \\
\hline & Villebramar (NMB) & Brunet 1979 & & 1 & 32.0 & 20.0 & - \\
\hline & Lagny-Torigny (MNHN) & from photograph of Bonis \& Brunet 2005 & & 1 & 31.0 & 19.0 & - \\
\hline & Kleinblauen (NMB-KB28) & Becker 2003 and this study & $\mathrm{m} 3$ & 1 & 33.5 & 20.5 & - \\
\hline & Möhren 13 (BSP) & from illustrations of Uhlig 1999 & & 1 & 27.5 & 18.5 & 9.0 \\
\hline & Villebramar (IPHEP) & Brunet 1979 & & 1 & 29.0 & 18.0 & - \\
\hline & Lagny-Torigny (MNHN) & from photograph of Bonis \& Brunet 2005 & & 1 & 32.0 & 19.0 & 10.0 \\
\hline & Kleinblauen (NMB-KB28) & Becker 2003 and this study & $\mathrm{d} 4$ & 1 & 24.5 & 16.0 & - \\
\hline & Möhren 13 (BSP) & from illustrations of Uhlig 1999 & & 1 & 23.0 & 15.5 & 7.0 \\
\hline \multirow[t]{2}{*}{ Plagiolophus ministri } & Kleinblauen (NMB-KB20) & this study & $\mathrm{m} 2$ & 1 & 19.0 & 11.0 & 12.5 \\
\hline & Villebramar (NMB-VBR114,116) & this study & & 2 & $19.0[18.0-20.0]$ & $10.0[9.5-10.5]$ & - \\
\hline Plagiolophus minor & Soumailles (NMB-SML21) & this study & $\mathrm{m} 2$ & 1 & 13.0 & 9.0 & - \\
\hline Plagiolophus ovinus & Ronzon (NMB-RO102) & this study & $\mathrm{m} 2$ & 1 & 14.0 & 8.0 & - \\
\hline Plagiolophus huerzeleri & Murs (NMB-OV132) & this study & $\mathrm{m} 2$ & 2 & $21.25[21.0-21.5]$ & $12.75[12.5-13.0]$ & - \\
\hline
\end{tabular}


very short. The other lower cheek teeth display an angular external groove vanishing before the neck, an angular trigonid with an acute dihedron, and a very low forward hypolophid in comparison to the metalophid. Teeth p3-4 display a waved labial cingulum (reduced under the protoconid on the specimens NMB-KB12 and NMB-KB29; Fig. 4p1-p3) and a weak lingual cingulum reduced under the metaconid, which can be very weakly constricted. The lingual valleys are low (same depth), the posterior one is U-shaped and the anterior one $\mathrm{V}$-shaped. The lower molars display a reduced labial cingulum, a low and medium long paralophid, V-shaped lingual valleys (the posterior one is broader than the anterior one), and sometimes the entoconid is extended by a short and thin forward branch. The lingual cingulum is absent.

Milk tooth d4 of the specimen NMB-KB29 (Fig. 4p1-p3), except thinner enamel and smaller size, has the same characters as the molars. It has neither constriction of the metaconid and the entoconid nor protoconid fold.

Discussion: The general dimensions, the developed lower canines in a hook shape, the concave backward ectoloph profile, the weak metacone folding and the marked parastyle on M1-2, the marked external groove, and the very low forward hypolophid (in comparison to the metalophid on lower cheek teeth) place the referred specimens in the subfamily Eggysodontinae (Heissig 1989; Bonis \& Brunet 1995; Uhlig 1999). The combination of mandibular and dental characters, including a spindly and low mandible, large lower canines with distal and mesial edges, a submolariform $\mathrm{P} 4$ with a strong continuous lingual cingulum, upper molars with a strong paracone folding, a weak antecrochet and a reduced lingual cingulum closing the median valley, a one-rooted $\mathrm{d} 1$, and lower premolars with a continuous to reduced labial cingulum and a lingual cingulum reduced under the metaconid, is typical of Eggysodon from the Oligocene of Europe (Uhlig 1999).

The specimens from Kleinblauen are similar in size to E. osborni and E. reichenaui, but markedly smaller than E. gaudryi and slightly smaller than E. pomeli, whereas the molarisation of P4 (submolariform) corresponds rather to that of E. gaudryi and E. pomeli (that of E. osborni being pre- to submolariform and that of E. reichenaui premolariform). The dental anatomies differ from E. gaudryi, E. reichenaui, and E. pomeli by a much reduced to absent labial cingulum on the cheek teeth and weaker metacone folding and antecrochet. On the other hand, they are very close to those of E. osborni from Möhren 13, widely described and figured by Uhlig (1999), notably for the angular external groove and the very low forward hypolophid in comparison to the metalophid of the lower cheek teeth, the weaker entoconid on $\mathrm{p} 2$, the low and medium long paralophid on lower molars, and the absence of protocone constriction on upper molars. However, the dimensions (Tab. 1) are slightly larger and the parastyle longer but similar to the specimens from LagnyThorigny. Following Uhlig (1999) and Becker (2003), and partially Roman (1911), the referred specimens can confidently be assigned to E. osborni. In particular, the mandible NMB-KB28 (figured by Uhlig 1999: pl. III) supports very close affinity with the specimen MNHN-OBP16 from Lagny-Thorigny (Bonis \& Brunet 1995: p. 183, tab. 1 \& pl. 1, fig. 2; Uhlig 1999: p. 148, tab. 121). In regard to the large size of the canines, this mandible probably belonged to a male adult, highlighting a great sexual dimorphism in the genus Eggysodon and maybe even in the family Hyracodontidae, as already suggested by Bonis \& Brunet (1995) and Uhlig (1999)

Equoidea HAY 1902

Palaeotheriidae BONAPARTE 1850

Plagiolophus POMEL 1847

Plagiolophus ministri BRUNET \& JEHENNE 1989

Referred material: Kleinblauen (NMB): m2 sin.(KB20; Fig. 4q1q2).

Description: The referred specimen displays two unfused angular crescents of the same dimension, an acute parastylid, a bulging praeprotocristid, a metastylid indistinguishable from the metaconid, a well-marked praehypocristid, a deep angular external groove, and a high and narrow hypoconulid. The lingual valleys are $\mathrm{V}$-shaped, the anterior one broader and the posterior one deeper. The entocingulid is reduced, closing the lingual valley, and the ectocingulid is present only at the level of the external groove.

Discussion: According to generic diagnostic characters (e.g., unfused crescents, indistinguishable metastylid, presence of a hypoconulid), $\mathrm{m} 2$ from Kleinblauen clearly belongs to the genus Plagiolophus. It was assigned to $P$. cf. fraasi by Stehlin (1914), but $P$. fraasi seems to have been frequently used as a "basket" taxon. Remy (2004), in his review of the genus Plagiolophus, attributed many specimens, ascribed to $P$. fraasi in the literature, to the species $P$. ringeadei or $P$. ministri. The dimensions (Tab. 1) and morphological features (e.g., high and narrow hypoconulid) of the referred specimen display the best similarities with those of Villebramar, which were ascribed to $P$. ministri (middle-sized species between $P$. ringeadei and P. huerzeleri) by Brunet \& Jehenne (1989) and by Remy (2004). According to these authors, the review of this specimen allows a new identification as $P$. ministri. This palaeotherid represents the only unambiguous occurrence in Switzerland of an endemic pre-"Grande Coupure" taxon recorded in the earliest Oligocene within a post-“Grande Coupure" assemblage.

In fact, the identification of an isolated metapod of a palaeotherid (McII dext. cast; NMB-UM6432) from the mammal locality of Vaulruz (Grès de Vaulruz Formation, Subalpine Molasse, southwestern Switzerland) is still uncertain, and moreover, this locality is poorly dated (Early Oligocene). Stehlin (1938) assigned it to Plagiolophus javali, Weidmann et al. (1982) suggested Palaeotherium medium suevicum (after an identification of J.L. Franzen), whereas J. Hürzeler (pers. comm. in the Register of the Tertiary Mammal-bearing localities of the Naturhistorisches Museum Basel; locality CH/1224/2) underlined similarities with the specimens from Villebramar (France). According to the last hypothesis, Weidmann (1993) signaled the palaeotherid specimen of Vaulruz as $P$. fraasi and

10 D. Becker 
attributed the locality to the mammal reference level MP22. Following the works of Brunet \& Jehenne (1989) and Remy (2004), the metapod should belong to P. ministri, but after my own observations, the dimensions of the specimen $(\mathrm{L}=129.0$; TDprox $=11.0 ;$ APDprox $=18.0 ;$ TDdia $=9.5 ;$ APDdia $=13.5$; TDdist $=14.5$; APDdist $=16.5)$ are strongly similar to those of Palaeotherium medium (comparison with an unregistered specimen cast of $P$. medium from the Naturhistorisches $M u$ seum Basel), that could then date the Vaulruz locality to the basal Oligocene (MP21?).

\section{Discussion}

\section{Biostratigraphy}

Figure 5 illustrates the occurrence of Late Eocene - Early Oligocene Eurasian rhinocerotoids, with emphasis put on the European record. The assemblages from Bressaucourt and Kleinblauen are typical for the Western European post-"Grande Coupure" fauna. They are composed by three families (Rhinocerotidae, Amynodontidae, Hyracodontidae) that arised with the mammal migration wave from Asia into Europe following this palaeobiogeographical event. The Kleinblauen faunal composition is further characterized by the presence of Plagiolophus ministri, an Early Oligocene representative of the pre-"Grande Coupure" European endemic Palaeotheriidae. Ronzotherium filholi, Eggysodon osborni and the genus Epiaceratherium are common in the mammal reference levels MP21-MP23 (e.g., Brunet 1979; Heissig 1989; Uhlig 1999). After Uhlig (1999), E. aff. magnum (top MP22-MP23) would be the derived form of Epiaceratherium magnum (MP21-base MP23). Cadurcotherium minus occurs in the well-dated localities of Bournoncle (MP21) and Barlières (MP22) in central-eastern France (Hugueney 1997). According to Brunet (1979), Bonis \& Brunet (1995), and Hugueney (1997), the older C. cayluxi - the second European Cadurcotherium species - is recorded in Isle-surSorgues (MP22-23), Étampes (MP24), Vendèze (MP24), and Garouillas (MP25). This suggests that the succession in the time C. minus - C. cayluxi seems to occur at MP22-23. Uhlig (1999) signals also Cadurcotherium sp. in Weinheim-Alzey (MP23), the only occurrence of this taxa in Germany. Finally, the biostratigraphical range of Plagiolophus ministri is restricted to the mammal reference level MP22 (Remy 2004).

The $R$. filholi and P. ministri specimens from Kleinblauen are analogous to those from the MP22 reference locality of Villebramar, whereas the E. magnum and E. aff. magnum specimens are closer to those of the type localities Möhren 13 (MP22) and Offenheim (MP23), respectively. On the other hand, the E. osborni specimens are rather close to those of Lagny-Thorigny (MP21), in particular with respect to the dimensions of the lower canines, but the Hyracodontidae morphometry is strongly variable, mainly due to high sexual dimorphism (e.g., Bonis \& Brunet 1995; Uhlig 1999). Moreover, Böhme (2001) signals unpublished material of Entelodon deguilhemi (Suiforme) in Kleinblauen (broken canine NMB-KB22) - a European taxon that is restricted to the mammal reference level MP22. Therefore, all these results permit to assign Kleinblauen to MP22 with confidence, as already suggested by Brunet (1979) and Becker (2003), but contrary to Uhlig (1999) who proposed a possible slightly older age (MP21-22). The combined occurrence of E. magnum and $E$. aff. magnum even suggests an age top MP22.

Initially, the age of Bressaucourt was dated lithostratigraphically to the local Rupelian Meeressand and biostratigraphically to the mammal reference level MP22 (e.g., Becker 2003; Picot et al.2008). However, the association of $R$. filholi (closer to the specimen from Villebramar, see discussion above) with C. minus (new identification, this work) suggests a new biostratigraphical interval corresponding to the interval MP21-MP22 for this locality.

Updating the results of Storni (2002) and Picot et al. (2008), the regional lithostratigraphical and biostratigraphical (calcareous nannoplankton, dinoflagellate cyst and mammal datings) data permit a good correlation with the European sequence chronostratigraphy (sensu Hardenbol et al. 1998) and calibration with the global time scale (Fig. 3). The transgression-regression cycles of the Rhenish sea during the Rupelian can so be related to the Pr4/Ru1 sequence of Hardenbohl et al. (1998) for the first, and to the Ru2 sequence of Hardenbohl et al. (1998) for the second cycle, respectively. As a result, the rhinocerotoids from Bressaucourt are probably related to the strictly continental beds of Conglomérats de Porrentruy, deposited just after the first Rhenish marine incursion and dated to the biostratigraphical interval MP21/22-base MP22 (ca. 32.6 Ma). According to the stratigraphical record of the earliest post-"Grande Coupure" fauna of the Hampshire Basin, the Paris Basin, and the Belgian Basin (Hooker et al. 2004, 2009), Bressaucourt occurred less than a million years after the highresolution stratigraphical interval of the "Grande Coupure" (ca. 33.6-33.4 Ma in Belgian Basin after Hooker et al. 2004, 2009). Regarding Kleinblauen, its stratigraphical position can be strengthened, as the local faunal record occurs at the end of the regressive phase of the second Rhenish marine incursion, corresponding to top MP22. This supports the biostratigraphical range proposed for both occurrences of E. magnum and E. aff. magnum.

\section{Palaeobiogeographical and palaeoenvironmental implications}

The association Epiaceratherium - Ronzotherium - Eggysodon is frequent in the earliest Oligocene of Western Europe, but especially in southwestern France, in Switzerland, and South Germany, occurring in Villebramar (MP22, Aquitaine Basin; Heissig 1969; Brunet 1979; Uhlig 1999), Kleinblauen (MP22, Swiss Molasse Basin), Ronheim 1 (MP22, German Molasse Basin; Heissig 1987; Uhlig 1999), and Espenshain (MP22, Weisselster Basin; Böhme 2001). On the other hand, the association Ronzotherium - Cadurcotherium is scarce and seems to be restricted to an area between central-eastern France and the western side of the Rhenish sea, the latter today naturalised by the Rhine Graben. The only well-dated 
localities are Bournoncle (MP21, Massif Central; Hugueney 1997), Barlières (MP22, Massif Central; Hugueney 1997) and Bressaucourt (MP21/22, north-central Jura Molasse). It seems that Eggysodon and especially Ronzotherium display no real geographical discrimination. The association Ronzotherium - Eggysodon is for exemple recorded in Lagny-Torigny (MP21, Paris Basin; Brunet 1979; Uhlig 1999). According to Uhlig (1999), Epiaceratherium could be a highly-specialized taxon living in swampy to humid forest, whereas Ronzotherium and Eggysodon would be more ubiquitous (Tab.2). In Cadurcotherium, the presence of cement and higher tooth crowns suggest a diet composed of abrasive elements such as grit (Blondel 2001). This taxon would also be a high-specialized taxon, but from dry open woodland (savanna). Mainly in accordance with the data of Uhlig (1999), Legendre (1989), Legendre \& Hartenberger (1992), Blondel (2001) and Popov et al. (2004; see map 2, evaporite deposits in Central France), this suggests that more open and arid environments existed in central-eastern France during the earliest Oligocene, in contrast to more forested and humid environements in southwestern France, Switzerland, and South Germany. The last two areas would have partially been disconnected from the western areas by the Rhenish sea, which could have been connected with the Perialpine sea during the Early Oligocene (Fig. 2; Fischer 1965; Reichenbacher et al. 1996; Sissingh 1997, 2003; Picot 2002; Roussé 2006; Pirkenseer 2007). The locations of Bressaucourt and Kleinblauen on both sides of the Rhenish sea, in relation with their relevant rhinocerotoid assemblages, is further evidence that the Rhenish and Perialpine seas were at least during certain time periods connected. However, the scarcity of Cadurcoterium localities and the low richness of the material makes palaeoenvironmental and palaeobiogeographical interpretations difficult. Cadurcoterium could have known sporadic short-time phases of dispersion from a possible endemic center in the Quercy, or a vast repartition combined with a high commonness only in the Quercy.

The palaeobiogeographical distribution of earliest Oligocene European rhinocerotoids and their temporal range ques-

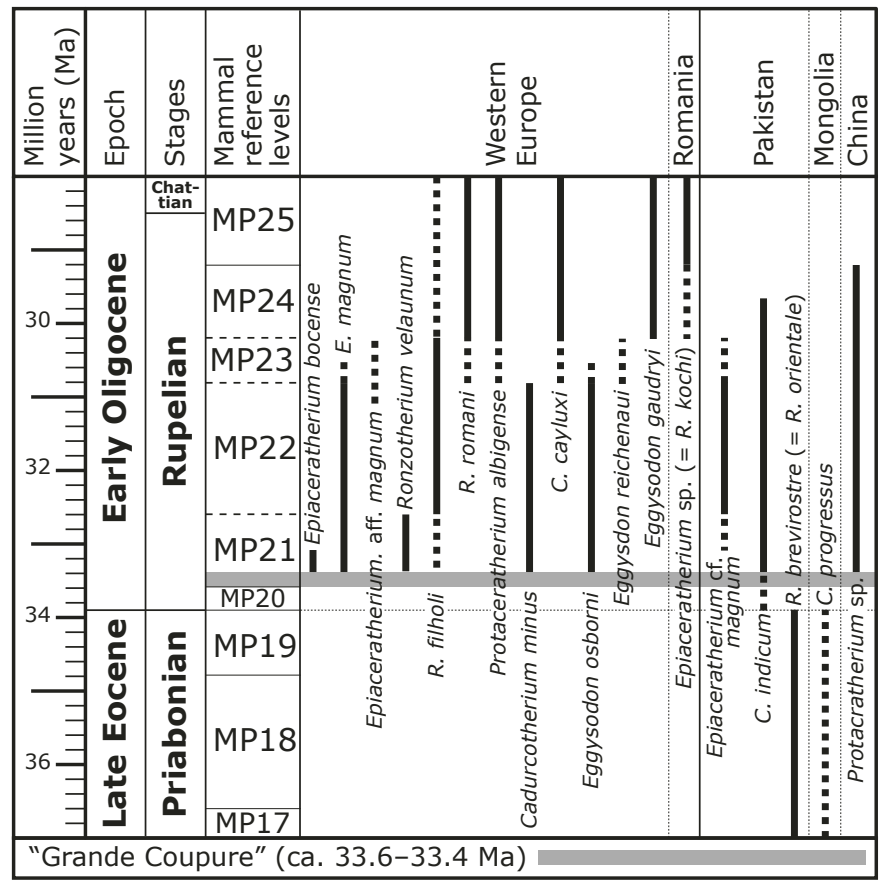

Fig. 5. Synthesis of the latest Eocene to Early Oligocene Eurasian rhinocerotoids with emphasis put on the Western Europe record. For the source of the data indicated in the first four columns refer to the caption of Figure 3. The time interval (ca. 33.6-33.4 Ma) of the "Grande Coupure" event (see Fig. 3) is based on high-resolution stratigraphy in the Belgian Basin after Hooker et al. (2004, 2009). Biochronostratigraphical ranges after Roman (1911), Heissig (1969), Brunet (1979), Dashzeveg (1991), Meng \& McKenna (1998), Uhlig (1999), Welcomme et al. (2001), Antoine et al. (2003), and Becker (2003).

tions the ways of their continental dispersal. Their Asian origin has been assumed for decades (e.g., Brunet 1979; Prothero \& Schoch 1989). Ronzotherium and Cadurcotherium had pre"Grande Coupure" representatives in Asia (Dashzeveg 1991; Meng \& McKenna 1998), Epiaceratherium occured in Early Oligocene from Pakistan (Antoine et al.2003), and Eggysodon could have been derived from an Eocene Asian taxon close to

Table 2. Overview of the different ecological parameters of Epiaceratherium magnum, Ronzotherium filholi, Cadurcotherium minus, and Eggysodon osborni as well as their related habitats. Body mass was estimated from regression on $\mathrm{m} 1$ area (Legendre 1989) and on occipital condyles-premaxilla length (Becker et al. 2009). Locomotion was based first on the slenderness of the McIII and secondary from MtIII and McII following the method of the gracility index (Guérin 1980): $100 \times$ TDdia/L. Dietary regime follows partially the subdivisions of Janis (1986): high browser feeding above ground level, regular browser feeding both above the ground and at ground level, and mixed feeder, and was characterised by the head holding that is a function of the feeding (Bales 1996) and by the Hypsodonty Index (sensu Guérin 1980:100 × H/L). The locomotion and the dietary regime of Cadurcotherium minus were partially estimated by analogies with C. cayluxi from Garouillas, because no skull and metapod of C. minus are documented. For the same reason, the head holding of Epiaceratherium magnum was partially estimated from E. bolcense and the closely-related American Trigonias, and Eggysodon osborni from small-sized relative Hyracodontinae.

\begin{tabular}{|c|c|c|c|c|c|}
\hline Taxa & Body mass & Locomotion & Dietary regime & Habitat & References \\
\hline Epiaceratherium magnum & ca. $600 \mathrm{~kg}$ & mediportal & (high?) browser & swampy (to humid) forest & Uhlig (1999); Becker (2003) \\
\hline Eggysodon osborni & ca. $300 \mathrm{~kg}$ & coursorial & high browser & humid (to dry) forest & Uhlig (1999); Becker (2003) \\
\hline Ronzotherium filholi & ca. $1000 \mathrm{~kg}$ & coursorial & regular browser & $\begin{array}{l}\text { dry to humid open woodland } \\
\text { (savanna) }\end{array}$ & $\begin{array}{l}\text { Becker (2003); Becker et al. } \\
(2009)\end{array}$ \\
\hline Cadurcotherium minus & ca. $500 \mathrm{~kg}$ & mediportal & mixed feeder & dry open woodland (savanna) & $\begin{array}{l}\text { Bonis \& Brunet (1995); Blondel } \\
\text { (2001) }\end{array}$ \\
\hline
\end{tabular}

12 D. Becker 
Prohyracodon or Teniseggysodon (Fig. 5; Uhlig 1999). However, Prohyracodon and other Asian-like mammals are recorded in the Late Eocene of Eastern Europe (Heissig 1989, 1990; Uhlig 1999), likely indicating earlier migration phases from Asia to Europe. As supposed by Baciu \& Hartenberger (2001), the northern Tethyan littoral was emerged, allowing migrations while the perialpine marine belt isolated Western Europe. The Western European post-"Grande Coupure" mammal dispersal could then have been investigated from North Italy via two secondary routes: a western route to southwestern France and a northern route to Switzerland and South Germany (Fig. 6). The mammal assemblage from the lignite beds of Monteviale (base MP21; Kotsakis et al. 1997; Uhlig 1999), although indicating no common elements at specific level between the Venetian area and Western Europe, displays strong similarities at genus level with the faunas of the German Molasse Basin (fissure-fills of Möhren, MP21-MP22) and northwestern Bohemia (Detan, MP21), and the Aquitaine Basin (Villebramar, MP22) (e.g., Fejfar 1987; Heissig 1987; Kotsakis et al. 1997; Uhlig 1999; Fejfar $\&$ Kaiser 2005). The more selective conditions of central-eastern France would have limited the colonisation to specialized taxa as Cadurcotherium and to ubiquist taxa as Ronzotherium and Eggysodon. However, according to recent palaeogeographical maps (Rögl 1999; Meulenkamp \& Sissingh 2003; Popov et al. 2004), there was no permanent link between North Italy and continental Western Europe during the earliest Oligocene. But these palaeogeographical data are based on maximal transgressive periods and possibly include too long time intervals. In fact, the faunal terrestrial assemblages record punctual migrations. This "two secondary routes" scenario is reasonable and in accordance with Kotsakis et al. (2004), but the alternative northern migration route - the Alpide belt route as suggested by Uhlig (1999) - from Kazakhstan or Mongolia can neither be excluded. In this case, the Rhenish sea would nevertheless have limited the migrations following temporarily available terrestrial ways.

Following the seasonal aridity conditions of the Early Oligocene related to a general decrease of the mean annual temperature (Legendre \& Hartenberger 1992) and to an overall deterioration in global climate (Pickering 2000), the Late Oligocene climatic conditions seem to have improved and became more homogeneous at a Western European scale, with the installation of patches of dry to humid forested environments (Legendre 1989; Legendre et al. 1995; Blondel 2001). This environmental transition could have permitted the establishment of the association Ronzotherium - Cadurcotherium - Eggysodon as recorded in Garouillas (MP25, Aquitaine Basin; Bonis 1995; Bonis \& Brunet 1995) or this could even be the reason for the early occurrence of Cadurcotherium in Weinheim-Alzey (MP23, Mainz Basin; Uhlig 1999).

\section{Conclusions}

The reviewed mammal remains of Bressaucourt represent the oldest well-dated post-"Grande Coupure" large mammal

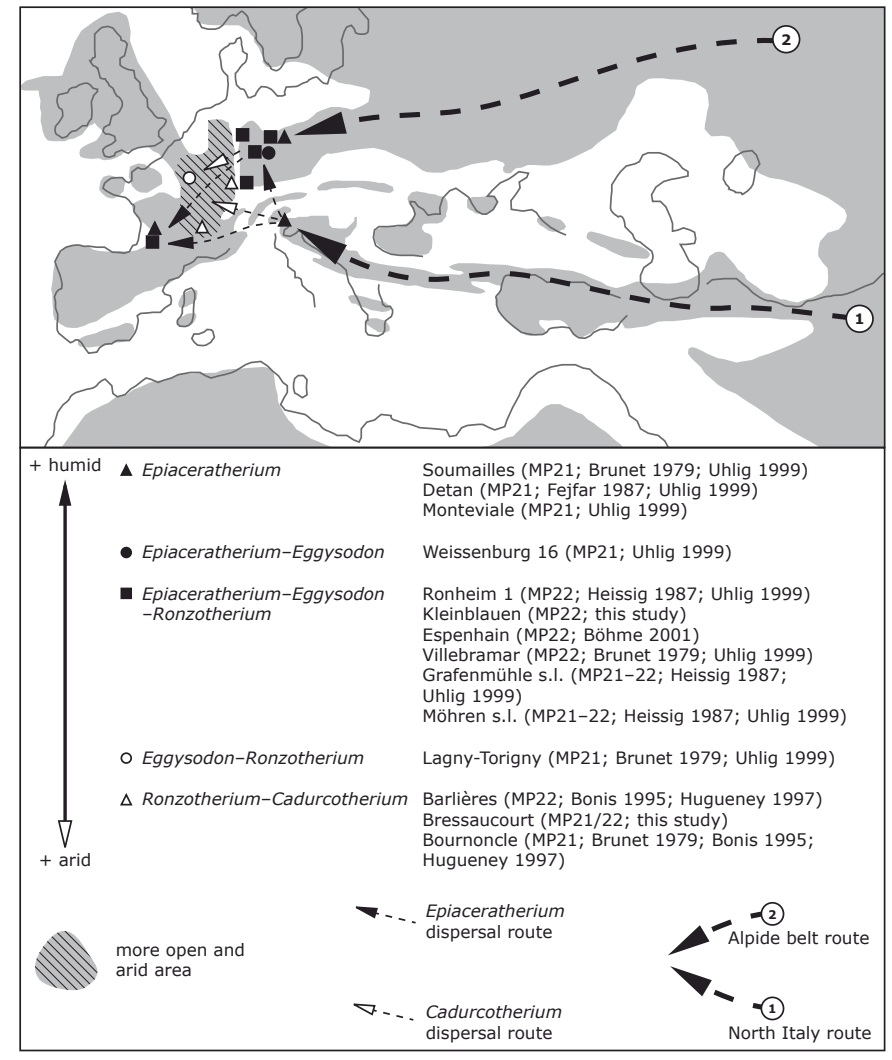

Fig. 6. Possible dispersal ways of rhinocerotoids during the earliest Oligocene (MP21-22) from Asia to Western Europe. Palaeogeographical map modified from Rögl (1999). The fissure-fill localities of Möhren s.l. and Grafenmühle s.l. include Möhren 4, 13, 7/16, 19, 20 and Grafenmühle 6B, 7, 11, 12, respectively, covering the mammal biostratigraphical interval MP21-22.

association, the only occurrence of Cadurcotherium, and the earliest occurrence of rhinocerotoids in Switzerland. The correlation of the Bresseaucourt mammal-bearing deposits with high-resolution stratigraphy permitted a dating of the fauna to ca. $32.6 \mathrm{Ma}$, which is less than one million years after the "Grande Coupure" event.

Regarding the assemblage of Kleinblauen, the coexistence of Epiaceratherium magnum and E. aff. magnum could suggest a new speciation within the Epiaceratherium lineage around the top of MP22. This locality represents the only well-dated Swiss post-"Grande Coupure" fauna with the persistance of an endemic pre-"Grande Coupure" palaeotherid (Plagiolophus ministri), because the isolated palaeotherid metapod of Vaulruz is not clearly identified and the locality is poorly dated.

Finally, the location of the Bressaucourt and Kleinblauen localities with respect to the Rhenish sea is crucial for the reconstruction of large mammal migration patterns, because the Rhenish sea and its eventuel connection with the Perialpine sea possibly was an important environmental barrier for the mammal dispersal during the earliest Oligocene. In combination with the repartition of similar rhinocerotoid associations 
in Western Europe, the reviewed associations of Bresseaucourt and Kleinblauen provide new insights into earliest Oligocene dispersal routes of mammals from Asia to Western Europe, suggesting that they arrived via the North Italy route rather than the Alpide belt route.

\section{Acknowledgements}

This project was financially supported by the Swiss National Science Foundation (project 200021-115995), the Swiss Federal Roads Authority, and the Office de la culture (Canton du Jura, Switzerland). I am grateful to Loïc Costeur and Burkart Engesser (Naturhistorisches Museum Basel, Switzerland), as well as to Ursula Menkveld-Gfeller and Bernhard Hostettler (Naturhistorisches Museum der Bürgergemeinde, Bern, Switzerland) for access to collections; to Marc Weidmann and Burkart Engesser for the informations about the stratigraphy of the Terre jaune of Delémont; to Gaëtan Rauber for his help in the realization of some figures; to Catherine Friedli for correcting the English. Also, I am indebted to Jean-Pierre Berger, Loïc Bocat, Jean-Paul BillonBruyat, Bastien Mennecart and Laureline Scherler for helpful corrections and discussions. The photographs were partly taken by Frédéric Lapaire, Bernard Migy and Laureline Scherler. The editor Daniel Marty, the guest associate editor Loïc Costeur, and the referees Kurt Heissig and Donald R. Prothero greatly improved the manuscript.

\section{REFERENCES}

Aguilar, J.-P., Agustí, J., Alexeeva, N. et al. 1997: Syntheses and correlation tables. In: Aguilar, J.-P., Legendre, S. \& Michaux, J. (Eds.): Actes du Congrès BiochroM'97. Mémoires et Travaux de l'Ecole pratique des Hautes Etudes, Institut de Montpellier 21,769-805.

Antoine, P.-O. 2002: Phylogénie et évolution des Elasmotheriina (Mammalia, Rhinocerotidae). Mémoire du Muséum national d'histoire naturelle de Paris 188, $359 \mathrm{pp}$.

Antoine, P.-O., Ducrocq, S., Marivaux, L., Chaimanee, Y., Crochet, J.-Y., Jaeger, J.-J. \& Welcomme, J.-L. 2003: Early rhinocerotids (Mammalia, Perissodactyla) from South Asia and a review of the Holarctic Paleogene rhinocerotid record. Canadian Journal of Earth Sciences 40, 365-374.

Baciu, C. \& Hartenberger, J.-L. 2001: Un exemple de corrélation marincontinental dans le Priabonien de Roumanie. Remarque sur la Grande Coupure. Comptes Rendus de l'Académie des Sciences de Paris 333, 441-446.

Bales, G.S. 1996: Skull evolution in the Rhinocerotidae (Mammalia, Perissodactyla): cartesian transformations and functional interpretations. Journal of Mammalian Evolution 3,261-279.

Becker, D. 2003: Paléoécologie et paléoclimats de la Molasse du Jura (OligoMiocène): apport des Rhinocerotoidea (Mammalia) et des minéraux argileux. PhD Thesis, University of Fribourg, GeoFocus 8, 327 pp.

Becker, D., Lapaire, F., Picot, L., Engesser, B. \& Berger, J.-P. 2004: Biostratigraphie et paléoécologie du gisement à vertébrés de la Beuchille (Oligocène, Jura, Suisse). Revue de Paléobiologie Vol. spéc. 9, 179-191.

Becker, D., Bürgin, T., Oberli, U. \& Scherler, L. 2009: A juvenile skull of Diaceratherium lemanense (Rhinocerotidae) from the Aquitanian of Eschenbach (eastern Switzerland). Neues Jahrbuch für Geologie und Paläontologie Abhandlungen 254, 5-39.

Berger, J.-P., Reichenbacher, B., Becker, D., Grimm, M., Grimm, K., Picot, L., Storni, A.,Pirkenseer, C. \& Schaefer, A. 2005a:Eocene-Pliocene time scale and stratigraphy of the Upper Rhine Graben (URG) and the Swiss Molasse Basin (SMB). International Journal of Earth Sciences 94, 711-731.

Berger, J.-P., Reichenbacher, B., Becker, D., Grimm, M., Grimm, K., Picot, L., Storni, A., Pirkenseer, C., Derer, C. \& Schaefer, A. 2005b: Paleogeography of the Upper Rhine Graben (URG) and the Swiss Molasse Basin (SMB) from Eocene to Pliocene. International Journal of Earth Sciences 94, 697-710.

Bitterli, P. 1945: Geologie der Blauen- und Landskronkette südlich von Basel. Beiträge zur Geologischen Karte der Schweiz N.F. 81, 73 pp.
Blondel, C. 2001: The Eocene-Oligocene ungulates from Western Europe and their environement. Palaeogeography, Palaeoclimatology, Palaeoecology 168, 125-139.

Böhme, M. 2001: Die Landsäugerfauna des Unteroligozäns der Leipziger Bucht - Stratigraphie, Genese und Ökologie. Neues Jahrbuch für Geologie und Paläontologie Abhandlungen 220, 63-82.

Bonis de, L. 1995: Le Garouillas et les sites contemporains (Oligocène, MP25) des phosphorites du Quercy (Lot, Tarn-et-Garonne, France) et leurs faunes de vertébrés. 9. Périssodactyles: Amynodontidae. Palaeontographica (A) 236,157-175.

Bonis de, L. \& Brunet, M. 1995: Le Garouillas et les sites contemporains (Oligocènes, MP25) des phosphorites du Quercy (Lot, Tarn-et-Garonne, France) et leurs faunes de vertebras. 10. Perissodactyla: Allaceropinae et Rhinocerotidae. Palaeontographica (A) 236, 177-190.

Brunet, M. 1979: Les grands mammifères chefs de file de l'immigration oligocène et le problème de la limite Eocène-Oligocène en Europe. Fondation Singer-Polignac (Ed.), Paris, 281 pp.

Brunet, M. \& Jehenne, Y. 1989: Révision des genres Plagiolophus Pomel, 1847 et Paloplotherium Owen, 1848, Mammalia, Palaeotheriidae du Paléogène d'Europe; intérêt biochronologique. Annales de Paléontologie 75, 23-52.

Brunet, M., Franzen, J.L., Godinot, M., Hooker, J.J., Legendre, S., SchmidtKittler, N. \& Vianey-Liaud, M. 1987: European Reference Levels and Correlation Tables. Münchner Geowissenschaftliche Abhandlungen 10,13-31.

Choffat, P. 1878: Découverte d'ossements fossiles dans le Nagelfluh du Porrentruy. L'Émulation jurassienne 1877, 262-264.

Dal Piaz, G. 1930: I Mammiferi dell' Oligocene veneto, Trigonias ombonii. Memorios dell'Instituto Geologico dell'Universita di Padova 9, 2-63.

Dashzeveg, D. 1991: Hyracodontids and Rhinocerotids (Mammalia, Perrissodactyla, Rhinocoerotoidea) from Paleogen of Mongolia. Palaeovertebrata $21,1-84$

Diebold, P., Laubscher, H.-P., Schneider, A. \& Tschopp, R. 1963: Blatt: 1085 Saint-Ursanne. Geologischer Atlas der Schweiz 1/25000. Geologische Aufnahme 40.

Emery, E. 2004: Le gisement de Rickenbach (canton de Soleure, Oligocène): étude paléontologique des grands mammifères et état actuel du bio-géotope. Unpublished Master Thesis, University of Fribourg, 129 pp.

Engesser, B.\& Mödden, C.1997: A new version of the biozonation of the Lower Freshwater Molasse (Oligocene, Agenian) of Switzerland and Savoy on the basis of fossil mammals. In: Aguilar, J.-P., Legendre, S. \& Michaux, J. (Eds.): Actes du Congrès BiochroM'97. Mémoires et Travaux de l'Ecole pratique des Hautes Etudes, Institut de Montpellier 21, 581-590.

Fejfar, O. 1987: A Lower Oligocene mammalian fauna from Detan and Dvèrce NW Bohemia, Czechoslovakia. Münchner Geowissenschaftliche Abhandlungen 10, 253-263.

Fejfar, O. \& Kaiser, T.M. 2005: Insect Bone-Modification and Paleoecology of Oligocene Mammal-Bearing Sites in the Doupov Mountains, Northwestern Bohemia. Palaeontologia Electronica 8,11 pp.

Fischer, H. 1965: Geologie des Gebietes zwischen Blauen und Pfirter Jura (SW Basel) mit einem mikropaläontologischen und einem paläogeographischen Beitrag. Beiträge zur Geologischen Karte der Schweiz N.F. 122, $107 \mathrm{pp}$.

Franzen, J.L. 2007: Eozäne Equoidea (Mammalia, Perisoodactyla) aus der Grube Messel bei Darmstadt (Deutschland). Schweizerische Paläontologische Abhandlungen 127, 245 pp.

Guérin, C. 1980: Les rhinocéros (Mammalia, Perissodactyla) du Miocène terminal au Pléistocène supérieur en Europe occidentale. Comparaison avec les espèces actuelles. Documents du Laboratoire de Géologie de l'Université de Lyon 79,1-401.

Hardenbol, J., Thierry, J., Farley, M., Jacquin, T., de Graciansky, P.-C. \& Vail, P. R.1998: Mesozoic and Cenozoic sequence chronostratigraphic framework of European basins. In: Graciansky, P.-C. de, Hardenbol, J. Jacquim, T. \& Vail, P.R. (Eds): Mesozoic and Cenozoic Sequence Stratigraphy of European Basins. SEPM Special Publication 60, 3-13, 763-781.

Hartenberger, J.-L. 1998: An Asian Grande Coupure. Nature 394, 321.

Heissig, K. 1969: Die Rhinocerotidae (Mammalia) aus der oberoligozänen Spaltenfüllung von Gaimersheim bei Ingolstadt in Bayern und ihre phylogenetische Stallung. Abhandlungen der Bayerische Akademie der Wissenschaften N.F. 138, 133 pp. 
Heissig, K. 1987: Changes in the rodent and ungulate fauna in the Oligocene fissure fillings of Germany. Münchner Geowissenschaftliche Abhandlungen 10,101-108.

Heissig, K. 1989: The allaceropine hyracodonts. In: Prothero, D.R \& R.M. Schoch, R.M. (Eds.): The Evolution of Perissodactyls. Oxford University Press, New York, 355-357.

Heissig, K. 1990: Ein Oberkiefer von Anthracohyus (Mammalia, ?Artiodactyla) aus dem Eozän Jugoslawiens. Mitteilungen der Bayerischen Staatssammlung für Paläontologie und historische Geologie 30, 57-64.

Hooker, J.J. 1987: Mammalian fauna events in the English Hampshire Basin (late Eocene-early Oligocene) and their application to European biostratigraphy. Münchner Geowissenschaftliche Abhandlungen 10, 109-116.

Hooker, J.J 1992: British mammalian communities across the Eocene-Oligocene transition and their environmental implications. In: Prothero, D.R. \& Berggren, W.A. (Eds): Eocene-Oligocene Climatic and Biotic Evolution. Princeton University Press, Princeton, 494-515.

Hooker, J.J. \& Weidmann, M. 2000: The Eocene mammal faunas of Mormont, Switzerland: Systematic revision and resolution of dating problems. Schweizerische Paläontologische Abhandlungen 120,143 pp.

Hooker, J.J., Collinson, M.E. \& Sille, N.P. 2004: Eocene-Oligocene mammalian faunal turnover in the Hamphire Basin, UK: calibration to the global time scale and the major cooling event. Journal of the Geological Society, London, 161, 161-172.

Hooker, J.J., Grimes, S.T., Mattey, D.P., Collinson, M.E. \& Sheldon, N.D. 2009: Refined correlation of the UK Late Eocene-Early Oligocene Solent Group and timing of its climate history. The Geological Society of America, Special Paper 452, 179-195.

Hugueney, M. 1997: Biochronologie mammalienne dans le Paléogène et le Miocène inférieur du Centre de la France: synthèse réactualisée. In: Aguilar, J.-P., Legendre, S. \& Michaux, J. (Eds.): Actes du Congrès BiochroM'97. Mémoires et Travaux de l'Ecole pratique des Hautes Etudes, Institut de Montpellier 21, 417-430.

Hugueney, M. \& Guérin, C. 1981: La faune de mammifères de l'Oligocène moyen de Saint-Menoux (Allier). Revue scientifique du Bourdonnais, Année 1981, 52-71.

Janis, C.M. 1986: An estimation of tooth volume and hypsodonty indices in ungulate mammals, and the correlation of these factors with dietary preferences. Mémoires du Museum National d'Histoire Naturelle, Paris (série C), 53, 367-387.

Jenny, F. 1905: Fossilreiche Oligocänablagerungen am Südhang des Blauen (Juragebirge). Verhandlungen der Naturforschenden Gesellschaft Basel $18,119-129$.

Kotsakis, T., Barisone, G. \& Rook, L. 1997: Mammalian biochronology in an insular domain: the Italian Tertiary faunas. In: Aguilar, J.-P., Legendre, S. \& Michaux, J. (Eds.): Actes du Congrès BiochroM'97. Mémoires et Travaux de l'Ecole pratique des Hautes Etudes, Institut de Montpellier $21,431-441$.

Kotsakis, T., Delfino, M. \& Piras, P. 2004: Italian Cenozoic crocodilians: taxa, timing and palaeobiogeographic implications. Palaeogeography, Palaeoclimatology, Palaeoecology 210, 67-87.

Laubscher, H.-P. 1963: Blatt: 1085 Saint-Ursanne. Geologischer Atlas der Schweiz 1/25000. Erläuterungen 40, $26 \mathrm{pp}$.

Legendre, S. 1989: Les communautés de mammifères du Paléogène (Eocène supérieur et Oligocène) d'Europe occidentale: structures, milieux et évolution. Münchner Geowissenschaftliche Abhandlungen 16,1-110.

Legendre, S. \& Hartenberger, J.-L. 1992: Evolution of Mammalian Faunas in Europe during the Eocene and Oligocene. In: Prothero, D.R. \& Berggren, W.A (Eds): Eocene-Oligocene Climatic and Biotic Evolution. Princeton University Press, Oxford, 516-528.

Legendre, S., Crochet, J.-Y., Godinot, M., Hartenberger, J.-L., Marandat, B., Remy, J.A., Sigé, B. Sudre, J. \& Vianey-Liaud, M. 1995: Évolution de la diversité des faunes de mammifères d'Europe occidentale au Paléogène (MP11 à MP30). Bulletin de la Société Géologique de France 162, 867874.

Lihoreau, F., Ducrocq, S., Antoine, P.-O., Vianey-Liaud, M., Rafaÿ, S., Garcia, G. \& Valentin, X. 2009: First complete skulls of Elomeryx crispus (Gervais, 1849) and of Protaceratherium albigense (Roman, 1912) from a new
Oligocene locality near Moissac (SW France). Journal of Vertebrate Palaeontology 29, 242-253.

Lucas, S.G. 2006: A new amynodontid (Mammalia, Perissodactyla) from the Eocene Clarno Formation, Oregono, and its biochronological significance. PaleoBios 26, 7-20

Luterbacher, H.P., Ali, J.R., Brinkhuis, H., Gradstein, F.M., Hooker, J.J., Monechi, S., Ogg, J.G., Powell, J. Röhl, U., Sanfilippo, A. \& Schmitz, B. 2004: The Paleogene Period. In: Gradstein, F.M., Ogg, J.G. \& Smith A.G. (Eds.): A Geological Time Scale. Cambridge University Press, Cambridge, 384408.

Meng, J. \& McKenna, M.C. 1998: Faunal turnovers of palaeogene mammals from Mongolian Plateau. Nature 394, 364-367.

Meulenkamp, J.E. \& Sissingh, W. 2003: Tertiary palaeogeography and tectonostratigraphic evolution of the Nothern and Southern Peri-Tethys platforms and the intermediate domains of the Africa-Eurasian boundary zone. Palaeogeography, Palaeoclimatology, Palaeoecology 196, 209228.

Mödden, C., Schäfer, P., Reichenbacher, B., Schwarz, J. \& Kadolsky, D. 2000: Säugertiere, Fisch-Otolithen, Ostracoden, Mollusken und Charophyten aus den Süsswasser-Schichten (Oligozän) von Wolfsheim im Mainzer Becken. Paläontologische Zeitschrift 74, 343-361.

Osborn, H.F. 1923: Cadurcotherium from Mongolia. American Museum Novitates 92,1-2.

Pickering, K.T. 2000: The Cenozoic world. In: Culver S.J. \& Rawson, P.F. (Eds): Biotic Response to Global Change. Cambridge University Press, Cambridge, 28-34.

Picot, L. 2002: Le Paléogène des synclinaux du Jura et de la bordure sudrhénane: paléontologie (Ostracodes), paléoécologie, biostratigraphie et paléogéographie. PhD Thesis, University of Fribourg, GeoFocus 5, $240 \mathrm{pp}$.

Picot, L., Becker, D., Lapaire, F., Ustaszewski, K., Hug, W.A. \& Berger, J-P. 2005: Sédimentologie, paléontologie et paléoenvironnements côtiers de la région de Porrentruy (Sud-Rhénan, Paléogène, Jura, Suisse): Implications géodynamiques. Eclogae geologicae Helvetiae 98, 281-296.

Picot, L., Becker, D., Cavin, L., Pirkenseer, C., Lapaire, F., Rauber, G., Hochuli, P. A., Spezzaferri, S. \& Berger, J.-P. 2008: Sédimentologie et paléontologie des paléoenvironnements côtiers rupéliens de la Molasse marine rhénane dans le Jura suisse. Swiss Journal of Geosciences 101, 483-513.

Pirkenseer, C. 2007: Foraminifera, Ostracoda and other microfossils of the Southern Upper Rhine Graben: palaeoecology, biostratigraphy, palaeogeography and geodynamic implications. Unpublished PhD Thesis, University of Fribourg, 340 pp.

Popov, S.V., Rögl, F., Rozanov, A.Y., Steininger, F.F., Shcherba, I.G. \& Kovac, M. (Eds) 2004: Lithological-Paleogeographical maps of Paratethys 10 maps Late Eocene to Pliocene. Courier Forschungsinstitut Senckenberg $250,1-46$.

Prothero, D.R. 1993: Fifty million years of rhinoceros evolution. In: Ryder, O.A. (Ed): Proceedings of the International Rhino Conference. San Diego Zoological Society, San Diego, 81-87.

Prothero, D.R. \& Schoch, R.M. 1989: Origin and evolution of the Perissodactyla: summary and synthesis. In: Prothero, D.R. \& Schoch, R.M. (Eds): The evolution of Perissodactyls. Oxford University Press, New York, 504-529.

Prothero, D.R., Manning, E. \& Hanson, C.B. 1986: The phylogeny of the Rhinocerotoidea (Mammalia, Perissodactyla). Zoological Journal of the Linnean Society 87, 341-366.

Prothero, D.R., Guérin, C. \& Manning, E. 1989: The history of the Rhinocerotoidea. In: Prothero, D.R. \& Schoch, R.M. (Eds): The evolution of Perissodactyls. Oxford University Press, New York, 322-340.

Reichenbacher, B., Berger, J.-P. \& Weidmann, M. 1996: Charophytes et otholithes de la Molasse d'eau douce inférieure oligocène de Moutier (Jura suisse). Neues Jahrbuch für Geologie und Paläontologie Abhandlungen 202, 63-93.

Remy, J.A. 2004: Le genre Plagiolophus (Palaeotheriidae, Perissodactyla, Mammalia): Révision systématique, morphologie et histologie dentaires, anatomie crânienne, essai d'interpretation fonctionnelle. Palaeovertebrata $33,1-275$. 
Rögl, F. 1999: Mediterranean and Paratethys. Facts and hypotheses of an Oligocene to Miocene palaeogeography (short overview). Geologica Carpathica 50, 339-349.

Roman, F. 1911: Les Rhinocérotidés de l'Oligocène d'Europe. Archives du Muséum d'histoire naturelle de Lyon 11, 92 pp.

Roman,F. \& Joleaud, L. 1908: Le Cadurcotherium de l'Isle-sur-Sorgues et révision du genre Cadurcotherium. Archives du Muséum d'histoire naturelle de Lyon 10, 52 pp.

Roussé, S. 2006: Architecture et dynamique des séries marines et continentales de l'Oligocène Moyen et Supérieur du Sud du Fossé Rhénan: évolution des milieux de dépôts en contexte de rift en marge de l'avant-pays alpin. Unpublished PhD Thesis, University Louis Pasteur, Strasbourg (France), 471 pp.

Simaeys van, S., Munsterman, D. \& Brinkhuis, H. 2005: Oligocene dinoflagellate cyst biostratigraphy of the Southern North Sea. Review of Palaeobotany and Palynology 134, 105-128.

Sissingh, W. 1997: Tectonostratigraphy of the North Alpine Foreland Basin: correlation of Tertionary depositional cycles and orogenic phases. Tectonophysics 282, 223-256.

Sissingh, W. 2003: Tertiary paleogeographic and tectonostratigraphic evolution of the Rhenish Triple Junction. Palaeogeography, Paleoclimatology, Palaeoecology 196, 229-263.

Stehlin, H.G. 1910: Remarques sur les faunules des mammifères des couches éocènes et oligocènes du Bassin de Paris. Bulletin de la Société Géologique de France 9, 488-520.

Stehlin, H.G. 1914: Übersicht über die Säugetiere der schweizerischen Molasseformation, ihre Fundorte und ihre stratigraphische Verbreitung. Verhandlungen der Naturforschenden Gesellschaft Basel 21, 165-185.

Stehlin, H.G. 1938: Über das Alter des Vaulruzsandsteins. Eclogae geologicae Helvetiae 31, 293-296.
Storni, A. 2002: Étude paléontologique et sédimentologique de la carrière d'Altkirch (Alsace, Paléogène) et cartographie des sédiments tertiaires et quaternaires de la région de Porrentruy. Unpublished Master Thesis, University of Fribourg, 125 pp.

Uhlig, U. 1999: Die Rhinocerotoidea (Mammalia) aus der unteroligozänen Spaltenfüllung Möhren 13 bei Treuchtlingen in Bayern. Abhandlungen der Bayerische Akademie der Wissenschaften, Mathematisch-Naturwissenschaftliche Klasse, Neue Folge 170, 254 pp.

Wall, W.P. 1989: The phylogenetic history and adaptive radiation of the Amynodontidae. In: Prothero, D.R \& Schoch, R.M. (Eds.): The Evolution of Perissodactyls. Oxford University Press, New York, 341-354.

Weidmann, M. 1993: Atlas géologique de la Suisse 1/25'000. Feuille: 1244 Châtel-St-Denis. Notice explicative. Service hydrologique et géologique national, Berne, 55 pp.

Weidmann, M., Homewood, P. \& Fasel, J.-M. 1982: Sur les terrains subalpins et le wildflysch entre Bulle et Montreux. Bulletin de la Société vaudoise des sciences naturelles 76 (362), 151-183.

Welcomme, J.-L., Benammi, M., Crochet, J.-Y., Marivaux, L., Métais, G., Antoine, P.-O. \& Baloch, I. 2001: Himalayan Forelands: palaeontological evidence for Oligocene detrital deposits in the Bugti Hills (Balochistan, Pakistan). Geological Magazine 138, 397-405.

Zachos, J., Pagani, M., Sloan, L., Thomas, E. \& Billups, K. 2001: Trends, Rhythms, and Aberrations in Global Climate 65 Ma to Present. Science 292, 686-693.

Manuscript received June 18, 2009

Manuscript accepted October 04, 2009

Editorial handling: Loïc Costeur \& Daniel Marty 